\title{
Inequality in Incomes and Access to Education: A Cross-country Analysis (1960-95)
}

\section{Daniele Checchi}

Abstract. In the current debate on the relationship between inequality in income distribution and growth, one of the possible links works through access to education. Starting from an optimal demand for education where, among other things, the years of education depend on family income, we derive two testable predictions in the analysis of aggregate data on school enrolments: a negative (linear) dependence of enrolment rates on the Gini concentration index on income distribution; and a positive dependence on public resources invested in education and/or on skill premium in the labour market. These predictions are tested on a (unbalanced) panel of 108 countries for the period 1960-95. The main finding of this analysis is that, once we control for the degree of development with the (log of) per capita output, financial constraints seem mainly relevant in limiting the access to secondary education. However, when considering gender differences, there is evidence that female participation in education is more conditioned by family

Daniele Checchi, Facoltà di Scienze Politiche, Università degli Studi di Milano, via Conservatorio 7, I-20122 Milan, Italy. Tel: +39-02-5032-1519 (dir.), ext. 1501 (secr.); Fax: +39-02-5032-15050; e-mail: daniele.checchi@unimi.it.

The first draft of this paper was written while the author was on a visiting sabbatical programme at WIDER-United Nations University (Helsinki). The author thanks all WIDER staff members for the friendly atmosphere, and especially Andrea Cornia for lengthy discussions. He appreciated the comments of the participants to the workshop on 'Inequality, Growth and Poverty under the Washington Consensus' (WIDER, Helsinki, July 1999), and in particular the remarks of my discussant, Sanjay Reddy. The author also thanks Sam Bowles, Giorgio Brunello, Luca Flabbi, Massimo Giannini and Fulvia Mecatti for comments on an earlier draft. Luca Flabbi has provided excellent research assistantship. An anonymous referee has made valuable comments. The paper also benefited from the comments from participants to seminars held at WIDER (Helsinki), the EAEPE conference (Prague), the EALE conference (Regensburg), Università Cattolica (Milan), IGIER Bocconi (Milan), Università degli Studi di Milano Bicocca, the University of Ancona and the CEPR seminar on Inequality (Bergen). Financial support from the University Ministry is gratefully acknowledged.

LABOUR 17 (2) 000-000 (2003)

JEL D31, I2 (C) 2003 CEIS, Fondazione Giacomo Brodolini and Blackwell Publishers Ltd, 9600 Garsington Rd., Oxford OX4 2DQ, UK and 350 Main St., Malden, MA 02148, USA. 
wealth, in some cases starting from primary education. Finally, there is weak evidence that public resources spent on education raise the enrolment rates.

\section{Introduction}

In recent years there has been a revival of interest in studying the relationship between inequality and growth. After the works by Kuznets in the 1950s (e.g. Kuznets, 1955), where the stages of growth were shaping the degree of inequality in society, the issue was neglected for almost 30 years, to reappear again at the beginning of the current decade. Starting with the empirical finding of a negative relationship between income inequality and growth of per capita income observed in different samples of countries in the last 30 years, several studies have proposed alternative explanations. Without any claim to completeness, one could group existing explanations into two main lines of research. ${ }^{1}$ The first one invokes political economy actions, in a context of asset market completeness. Greater inequality raises the demand for fiscal redistribution and introduces distortions that hamper private investment decisions. ${ }^{2}$ An empirical variant of the same idea is that (wealth) inequality makes turmoil more likely (e.g. the lack of land reform), increases political instability, makes investors' horizons shakier and eventually reduces output growth. ${ }^{3}$ In both cases it is the increasing threat of reduction in the return of invested capital (or even the risk of expropriation) that reduces the agents' willingness to invest in physical capital, thus depressing the potential for growth.

The second line of research considers the borrowing constraints in financing access to education as the main explanation for the negative correlation between inequality and growth. ${ }^{4}$ The poorest parts of the population do not possess resources to access education and cannot find financial markets where they can borrow these resources to send their children to school. ${ }^{5}$ In this case, fiscal redistribution is efficient because it shifts resources from individuals with low rates of return to liquidity-constrained agents with very high rates of return. ${ }^{6}$

Empirical tests of these two lines of research are still inconclusive. Most authors find a negative correlation between inequality and growth, ${ }^{7}$ but other contradictory results can be found in the literature. ${ }^{8}$ The real question is that it is not yet clear through which variables it operates. The political economy explanation suffers from a lack of evidence for a negative relationship between redistribution and growth. ${ }^{9}$ Alesina and Perotti (1996) found evidence of 
a negative relationship between inequality and growth via a variable measuring political instability (first principal component extracted from numbers of riots, assassination, coups); but their analysis has no predictive power, and the possibility of measuring political instability is questionable. ${ }^{10}$ It is more difficult to test the second line of research in the absence of information at the individual level about income and educational choices of the family. Using aggregate data, Perotti (1994) found that a subjective qualitative measure of credit market rationing is statistically significant in explaining growth only when interacted with income inequality. However, the most convincing piece of evidence in this respect comes from the comparison between Far Eastern countries and Latin American ones. The former are characterized by lower inequality and greater access to school, whereas the latter exhibit the reverse situation; possibly for these different patterns, the first area experienced sustained growth during the 1970s and 1980s, while the second area underwent stagnation. ${ }^{11}$ Using household surveys for 35 countries, Filmer and Pritchett (1998) have shown that asset poverty (as measured by the first principal component extracted from information on ownership of durable goods and quality of housing) reduces school attainment in the poorest 40 per cent of the population. Using aggregate data for a limited sample of countries, Flug et al. (1998) found that secondary school enrolments are affected negatively by income inequality.

The present study provides additional support to this second line of research. It starts with an optimal demand for education and explores under which conditions the number of years of schooling can be correlated to family income. On one side, optimal demand for schooling could be positively associated with unobservable ability; if ability is transmitted intergenerationally, we could get positive correlation between family income and children's schooling. On the other side, if liquidity constraints prevent school attendance by children from poor families, we observe correlation between educational choices and family incomes, at least in the lower tail of income distribution. We then prove that, under given assumptions, enrolment rates and measures of income inequality (namely the Gini index) should be negatively correlated. However, following the liquidityconstraints explanation, the Gini coefficient should be negatively correlated each time missing financial markets create a barrier to accessing education for the poorest families. Contrariwise, if the intergenerational transmission of talent is a valid explanation, educational attainments and income distribution should be positively 
correlated at any stage of education. Since our empirical estimates prove a robust negative correlation at the secondary level for all the population, and at primary and tertiary levels for a gender component only, we believe that these results bring support to the view that poor families are prevented from accessing school by their low incomes. Thus, greater income inequality reduces access to school. Provided cumulated human capital affects income growth, ${ }^{12}$ we strengthen the second line of interpretation of the negative relationship between inequality and growth.

The paper is organized as follows. The next section studies the relationship between individual demand for schooling and aggregate distribution of income. Section 3 describes the data set and Section 4 presents the estimates of school enrolment rates at different levels (primary, secondary and tertiary) in an unbalanced panel of 108 countries for the period 1960-95. The final section contains concluding remarks.

\section{Individual demand for education and aggregate income distribution}

Following the work of Becker (1993) and Card (1999), the optimal demand for schooling is derived by equating decreasing marginal benefits (because lengthening school attendance reduces working life) and increasing marginal cost (because of the direct cost of higher stages of education and the opportunity cost of foregone incomes). The demand for schooling decreases with the intertemporal discount rate and with direct costs of schooling, and increases with the return to education and the resources publicly invested in education (provided they increase the production of human capital). When agents are heterogeneous in ability, better talented children obtain more human capital (because they benefit more from schooling and they stay longer at school) and therefore earn more (Card, 1999). When agents are heterogeneous in family income and financial markets are imperfect, children from poor families obtain less education because they face higher costs, and earn less in the labour market. These two polar cases of heterogeneity, respectively named 'elitist' and 'equalitarian' by Becker (1993), rather then being mutually excluding, usually coexist. Both heterogeneities can be transmitted intergenerationally. Inequality in family resources may prevent access to education, thus re-creating income inequality in the next generation. Contrariwise, when un- 
observable ability is correlated across generations, better-endowed parents are more likely to get endowed children. In both cases we empirically observe low intergenerational mobility in educational achievements and measures. Thus, when we take a snapshot of income distribution, we are unable to distinguish whether the poor are so because they are less talented or because they are the descendants of poor families. ${ }^{13}$ Unless one has access to individual data with reasonable proxies for unobservable ability for at least two generations, the two cases are observationally equivalent. The debate between supporters of a 'natural' explanation and defenders of the 'imperfect market' explanation of inequality has not yet reached a definite conclusion, given the lack of natural experiments to discriminate between the two, and we suspect it never will. ${ }^{14}$ Since individual data sets containing proxy variables for ability do not exist for a sufficient number of countries, we have to resort to indirect aggregate evidence. If educational achievements and family incomes are correlated across generations at the level of individuals (either for imperfect financial markets or for persistence in unobserved ability), then the distribution of income in one generation is correlated with access to education in the next one. The shape of this relationship is the object of our investigation.

We start with a standard human capital relationship between earned income and educational achievement:

$$
X_{i t+1}=f\left(\begin{array}{c}
S_{i t}, H_{i t} \\
+
\end{array}\right)+\varepsilon_{i t+1} \text {. }
$$

The income $X_{i t+1}$ earned by individual $i$ when an adult depends on her educational achievement when young $S_{i t}$, on her endowment of unobservable ability $H_{i t}$, and on good/bad luck in the labour market $\varepsilon_{i t+1}$. If the individual maximizes her expected income, given a budget constraint (where the access to education can be limited by inherited family resources) and a 'production' technology for human capital, we obtain the optimal choice of schooling:

$$
S_{i t}=g\left(\begin{array}{c}
H_{i t}, X_{i t} R_{t}, E_{t} \\
++
\end{array}\right) \text {. }
$$

The individual will demand more education the higher her unobservable ability $H_{i t}$ (because talented people have more success in school, drop out less and stay in school longer), the higher the family income $X_{i t}$ (since family income can limit the access to education when financial markets are imperfect or even absent), the higher the expected return of education in the labour market $R_{t}$, 
and the higher the public resources invested in education $E_{t}$ (which may lower the access cost to education, provide better-quality education and/or improve the cultural environment).

If unobserved ability is correlated across generations:

$$
H_{i t}=h\left(\begin{array}{c}
H_{i t-1} \\
+
\end{array}\right)
$$

By replacing equation [3] into equation [1] we get:

$$
S_{i t}=g\left(\begin{array}{c}
h\left(H_{i t-1}\right), X_{i t} R_{t}, E_{t} \\
+++_{+}
\end{array}\right) .
$$

By lagging equation [1] by one generation and inverting with respect to parents' ability (Becker, Tomes, 1986) we obtain:

$$
H_{i t-1}=l\left(\begin{array}{c}
S_{i t-1}, X_{i t} \\
+
\end{array}\right) .
$$

Finally by introducing equation [5] into equation [4] we get:

$$
S_{i t}=g\left(h\left(l\left(S_{i t-1}, X_{i t}\right)\right), X_{+} R_{t}, E_{t}\right) .
$$

In this way we see that parents' income is correlated with their children's educational choices through two possible channels. The former (which we term 'ability') summarizes the fact that brighter parents earn more, give birth to brighter children, who in turn achieve more education. The latter (which we term 'liquidity constraint') indicates that under imperfect financial markets the poorest fraction of the population may be prevented from accessing school. If we log-linearize equation [6] we obtain:

$$
s_{i t}=\alpha_{0}+\alpha_{1} s_{i t-1}+\alpha_{2} x_{i t}+\alpha_{3} x_{i t}+\alpha_{4} \rho_{t}+\alpha_{5} e_{t},
$$

where $s_{t}=\log \left(S_{t}\right), x_{t}=\log \left(X_{t}\right), \rho_{t}=\log \left(R_{t}\right)$ and $e_{t}=\log \left(E_{t}\right)$. The case $\alpha_{2} \neq 0$ suggests ability persistence, whereas $\alpha_{3} \neq 0$ indicates liquidity constraints. In principle, two cases could be empirically discriminated. ${ }^{15}$ Since our theoretical expectations are $\alpha_{2}>0$ and $\alpha_{3} \geq$ 0 (zero being the limiting case of perfect financial markets), if we do not find evidence of correlation between children's educational choices and parents' incomes we can infer that both 'ability' and 'liquidity constraints' channels of persistence are absent. Contrariwise, finding positive correlation potentially allows for both explanations. However, the 'ability' channel should operate at all stages of education (i.e. $\alpha_{2}$ must be positive at all stages of educational choice), whereas the 'liquidity' channel could operate at some stages 
of education but not at others (typically for non-compulsory and/or lower stages of education). But we cannot proceed any further without individual information about education and family background, and unfortunately these data sets exist mainly for developed countries and for recent years.

If we wish to extend our analysis to a larger set of countries and years, we have to resort to aggregate information. Therefore, we need to develop the aggregate implications of the model described by equation [7]. We introduce the assumption that incomes $X$ are $\log$-normally distributed, that is $\log (X)=x \sim N\left(\mu_{x}, \sigma_{x}^{2}\right)$. As a consequence of the log-linearity of equation [7], educational choices will be normally distributed in the subsequent generation, conditional on the 'ability' and/or the 'liquidity' channel being operative. We will exploit known properties of normal distributions to prove the following proposition:

Proposition 1: Under the assumptions of validity of model [7] and log-normal distribution for incomes $\mathrm{X}$, and conditional on a given income mean, the enrolment rates to school (namely the proportion of the reference population attending school) are linearly related to specific inequality measures (like the Gini concentration index) obtained from income distribution.

Proof. The enrolment rate $P$ represents the fraction of the population aiming to achieve an amount of education exceeding the legal duration of a given stage of school. In symbols:

$$
\begin{aligned}
& P_{1}=\text { primary school enrolment }=\int_{n_{1}}^{\infty} f(S) \mathrm{d} S \\
& P_{2}=\text { secondary school enrolment }=\int_{n_{2}}^{\infty} f(S) \mathrm{d} S \\
& P_{3}=\text { tertiary school enrolment }=\int_{n_{3}}^{\infty} f(S) \mathrm{d} S,
\end{aligned}
$$

where $n_{1}, n_{2}$ and $n_{3}$ are, respectively, the numbers of years required to complete the primary, secondary or tertiary level of education, and $f(S)$ is the density function of $S$. The Gini concentration index on income distribution can be represented as: ${ }^{16}$

$$
G_{X}=\int_{0}^{\infty} 2[F(X)-Q(X)] g(X) \mathrm{d} X, Q(X)=\frac{1}{\bar{X}} \int_{0}^{X} t g(t) \mathrm{d} t,
$$

where $g(X)$ is the density function of $X$ and the term in square brackets is the vertical distance between the Lorenz curve and the 
perfect equality relationship. Given the log-normality assumption, $\log (X)=x \sim N\left(\mu_{x}, \sigma_{x}^{2}\right)$ and its density function is given by:

$$
N\left(x ; \mu_{x}, \sigma_{x}^{2}\right)=\frac{1}{\sigma_{x} \sqrt{2 \pi}} \exp \left[-\frac{\left(x-\mu_{x}\right)^{2}}{2 \sigma_{x}^{2}}\right] .
$$

The associated Gini index is:

$$
\begin{aligned}
G_{X} & =2 \int_{-\infty}^{\frac{\sigma_{x}}{\sqrt{2}}} \frac{1}{\sqrt{2 \pi}} \exp \left[-\frac{t^{2}}{2}\right] \mathrm{d} t-1 \\
& =2 \int_{-\infty}^{\frac{\sigma_{x}^{2}}{\sqrt{2}}+\mu_{x}} \frac{1}{\sigma_{x} \sqrt{2 \pi}} \exp \left[-\frac{\left(x-\mu_{x}\right)^{2}}{2 \sigma_{x}^{2}}\right] \mathrm{d} t-1 .
\end{aligned}
$$

We can rewrite equation [7] in a more compact form as:

$$
s_{i t}=\gamma_{0}+\gamma_{1} x_{i t}
$$

where $\gamma_{0}$ incorporates all shift parameters for the entire distribution. As a consequence of the linearity assumption, $s$ is normally distributed, i.e. $s \sim N\left(\gamma_{0}+\gamma_{1} \mu_{x}, \gamma_{1}^{2} \sigma_{x}^{2}\right)$ and its density function is given by:

$$
\begin{aligned}
N\left(s ; \gamma_{0}+\gamma_{1} \mu_{x}, \gamma_{1}^{2} \sigma_{x}^{2}\right) & =\frac{1}{\sqrt{2 \pi\left(\gamma_{1}^{2} \sigma_{x}^{2}\right)}} \exp \left[-\frac{\left(s-\gamma_{0}-\gamma_{1} \mu_{x}\right)^{2}}{2\left(\gamma_{1}^{2} \sigma_{x}^{2}\right)}\right] \\
& =\frac{1}{\gamma_{1} \sigma_{x} \sqrt{2 \pi}} \exp \left[-\frac{\left(x-\mu_{x}\right)^{2}}{2 \sigma_{x}^{2}}\right] .
\end{aligned}
$$

Enrolment rates can now be redefined as: ${ }^{17}$

$$
\begin{aligned}
P_{i} & =\int_{\log \left(n_{i}\right)}^{\infty} f(s) \mathrm{d} s=1-\int_{-\infty}^{\log \left(n_{i}\right)} f(s) \mathrm{d} s=1-\int^{\frac{\log \left(n_{i}\right)-\gamma_{0}}{\gamma_{1}}} \frac{1}{\gamma_{1}} f(x) \gamma_{1} \mathrm{~d} x \\
& =1-\frac{1}{2}\left[2 \int_{-\infty}^{\frac{\sigma_{x}^{2}}{\sqrt{2}}+\mu_{x}} f(x) \mathrm{d} x+2 \int_{\frac{\sigma_{x}^{2}}{\sqrt{2}}+\mu_{x}}^{\frac{\log \left(n_{i}\right)-\gamma_{0}}{\gamma_{1}}} f(x) \mathrm{d} x\right] \\
& =\left[\frac{1}{2}-\int_{\frac{\sigma_{x}^{2}}{\sqrt{2}}+\mu_{x}}^{\frac{\log \left(n_{i}\right)-\gamma_{0}}{\gamma_{1}}} f(x) \mathrm{d} x\right]-\frac{1}{2}\left[2 \int_{-\infty}^{\frac{\sigma_{x}^{2}}{\sqrt{2}}+\mu_{x}} f(x) \mathrm{d} x-1\right] \\
& =\lambda_{j}\left(\mu_{x}\right)-\frac{1}{2} G_{X}, \quad j=1,2,3 .
\end{aligned}
$$


The intuition underlying this relationship can be grasped with reference to Figure 1. In the upper quadrant there are two normal density functions, the solid line corresponding to the case of $\mu_{x}=$ $0, \sigma_{x}^{2}=1$, and the dashed line to the case of $\mu_{x}=0, \sigma_{x}^{2}=2$. This translates below into the corresponding cumulative distribution function (north-east quadrant). Assuming a linear combination of the type $s=0.5+0.8 \cdot x$ (south-east quadrant), this maps the cumulative distribution function of $s \sim N(0.5,0.64)$ or $s \sim N(0.5,1.28)$ (south-west quadrant). In the last (north-west) quadrant we have reported the Lorenz curve corresponding to the distribution of $X{ }^{18}$ Now let us consider an increase in the dispersion of incomes around a given mean (i.e. the passage from the solid to the dashed line). This implies an increase in the population share with an income below any given value, and correspondingly an increase in the population share that is unable to achieve the income threshold that is necessary to access a fixed amount of education. At the same time, the Gini concentration index for incomes increases. We find corroboration of the negative association of the Gini index for incomes and school participation rates. ${ }^{19}$

Summing up, in the context of optimal demand of schooling with heterogeneous agents we have shown that educational attainment and family income are positively correlated. As long as it is possible to control for the mean income and other variables affecting the educational choice in the aggregate (cost of accessing the school, public resources devoted to education, wage premium for educated workers in the labour market and stage of development), we expect to find a negative relationship between the Gini concentration index on income distribution and enrolment rates at any level of education. In the sequel we find an existing negative relationship either at the secondary level of education or for the female component only. These results are incompatible with a relationship between educational achievement and family income based on the transmission of talent. In fact, if the brightest students are the offspring of the richest families, we should observe the same relationship subsisting at any stage of education and for both the male and female components of the young cohorts. Contrariwise, finding that this relationship exists for specific educational choices (going beyond compulsory education or investing in a daughter's future) does not contradict the idea of existing liquidity constraints in educational choices. 
Figure 1. The effect of an increase in income distribution

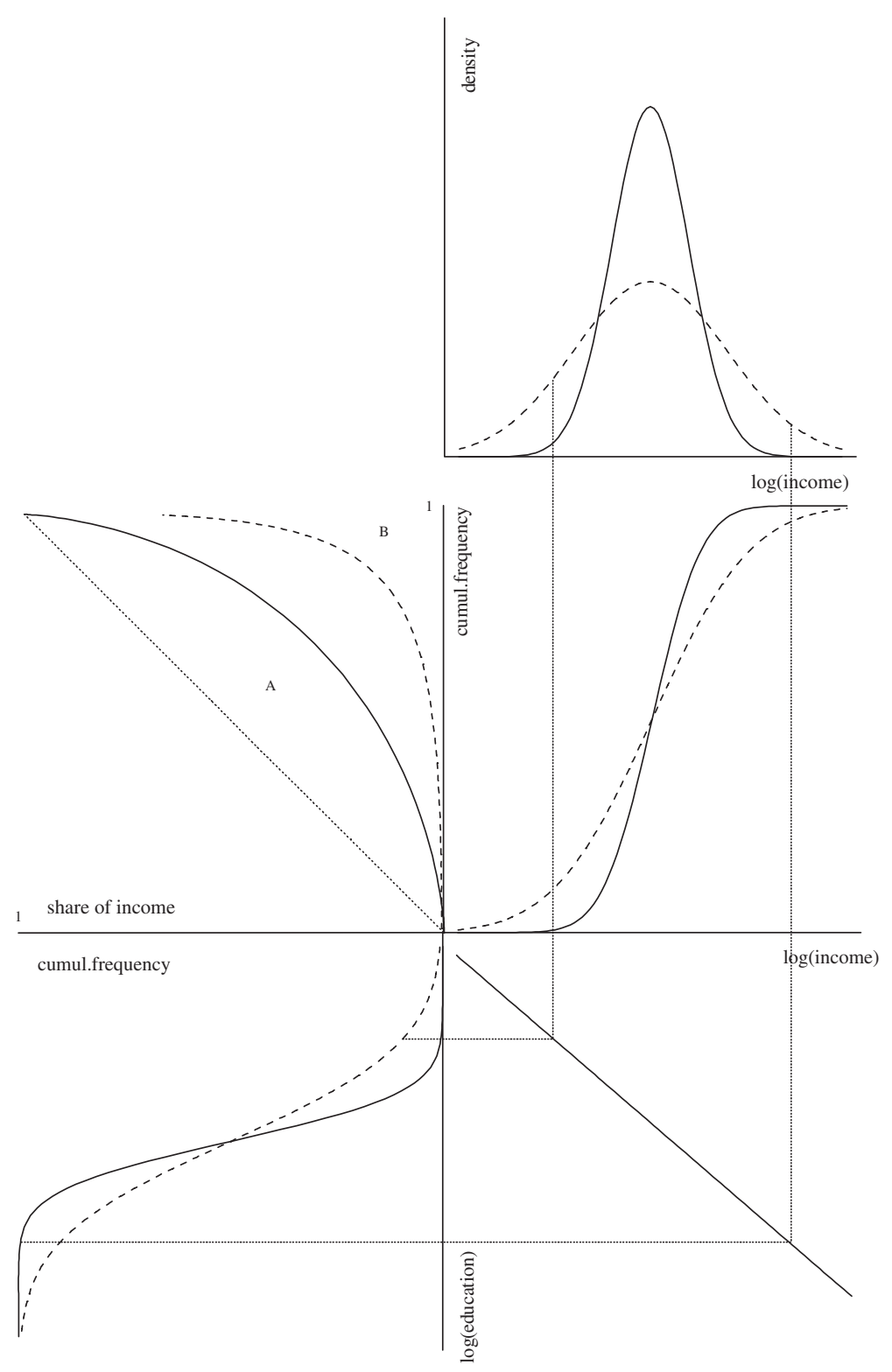

(c) CEIS, Fondazione Giacomo Brodolini and Blackwell Publishers Ltd 2003. 


\section{Data description}

The data utilized in this analysis come from different sources: data on educational achievements and school quality are from Barro and Lee $(1993,1994,1996,1997) ;{ }^{20}$ data on income inequality are from Deininger and Squire (1996); ${ }^{21}$ data on physical capital stocks are from Nehru and Dhareshwar (1993); finally, data on female fertility, child mortality and population growth have been extracted from the World Bank (1998). In all cases the series have been updated to 1995, when available, using World Bank (1998) and UNESCO (1998) data. Data refer to 108 countries for the period 1960-95 and report information at quinquennial intervals: therefore, at best we have eight observations for each country. However, with a theoretical dimension of the data set equal to 864 observations $(108 \times 8)$, missing information (mainly on income distribution) reduces it by more than one-third, transforming it into an unbalanced panel. For the main variables (income inequality indices, enrolment rates, gross national product and population) we rely on 470 observations (with an average of 4.3 observations per country), but in most cases when considering additional information this number has to be reduced even further. Descriptive statistics about these main variables are reported in Table 1 (entire data set), whereas information on additional control variables available is reported in Table A2 in the Appendix. Regional averages are also reported in the Appendix (Tables A1a-A1g).

On the whole, these data cover almost half of the 210 countries listed by the World Bank (1998), but account for 86.3 per cent of the world population (as measured in 1990). Given the fact that this data set is forcibly tailored according to the availability of income distribution data, one may suspect the possible introduction of sample bias. In order to check this possibility, using all the available information on a larger sample of 132 countries, we have run a panel probit regression predicting the availability of data on income distribution (see Table A3 in the Appendix). The results are reassuring: there is only evidence of easier availability of data for larger countries (in terms of population) and for less recent years. In particular, availability of information on income distribution seems unrelated to information on school enrolment at primary and secondary level, whereas it is positively correlated with higher education (since countries with a better-educated labour forces have easier access to income data). Therefore, we think that this data set 


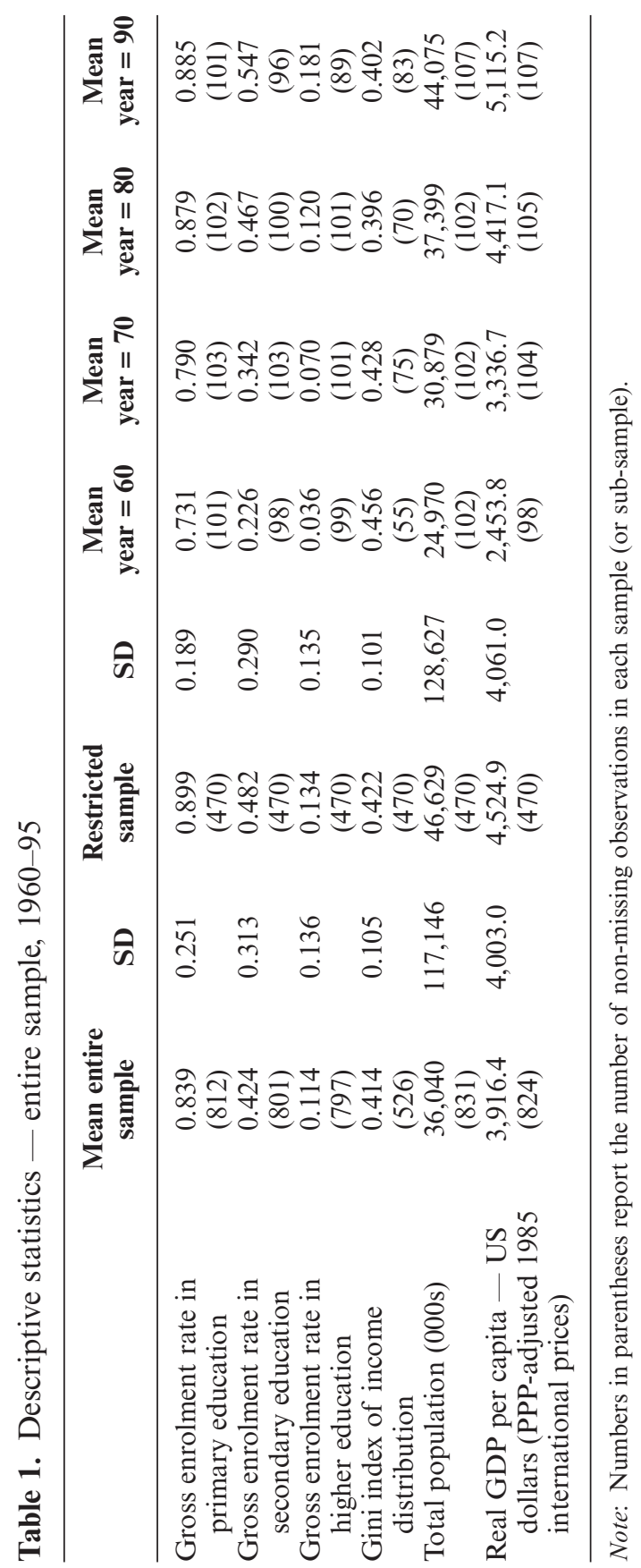

(c) CEIS, Fondazione Giacomo Brodolini and Blackwell Publishers Ltd 2003. 
may provide a representative picture at world level of the determinants of schooling participation.

Looking at the descriptive statistics (Table 1), we find evidence of well-known stylized facts. In the aggregate data, inequality in income distribution declined during the 1960s and the 1970s, then showed an upward surge during the 1980s. However, when looking at regional areas, we cannot find a uniform pattern, thus providing some support to the argument that inequality does not exhibit a specific trend since $1960 .^{22}$ Inequality is highest in sub-Saharan Africa and Latin America, and lower in industrialized countries and South Asia. Educational achievements rose quickly during the first two decades, but this rise slowed during the 1980s. By the beginning of the 1990s, many countries ended up having all the population enrolled in primary education (OECD countries, Latin America, North Africa and East Asia). However, while OECD countries have almost reached complete saturation also for the second stage of secondary education, all the other countries are still lagging behind, the worst situation being recorded for sub-Saharan and SouthAsian countries. An analogous picture emerges when looking at higher education. Graphical inspection of the association between school enrolment and income inequality confirms that most of the countries have achieved full participation in education at the primary level, thus reducing the potential variation in the former variable (see Figure 2). Contrariwise, at the secondary and tertiary levels of education, a negative correlation emerges clearly (see Figures 3 and 4). However, at this stage we do not know whether this evidence is the result of spurious correlation (when, for example, inequality and school participation are both functions of the stage of development) or whether it represents a genuine effect. To ascertain the nature of this effect we have to move to multivariate regressions.

\section{Empirical analysis}

In the sequel we investigate the determinants of enrolment rates at different stages of education, and in particular we will concentrate on the effects of income distribution. ${ }^{23}$ In line with the model introduced in Section 2, the observed enrolment rate is a reduced form incorporating elements describing household behaviour (demand for schooling) and government provision of this public service (supply of schooling). ${ }^{24}$ On the supply side, information 
Figure 2. Income inequality and education - primary education
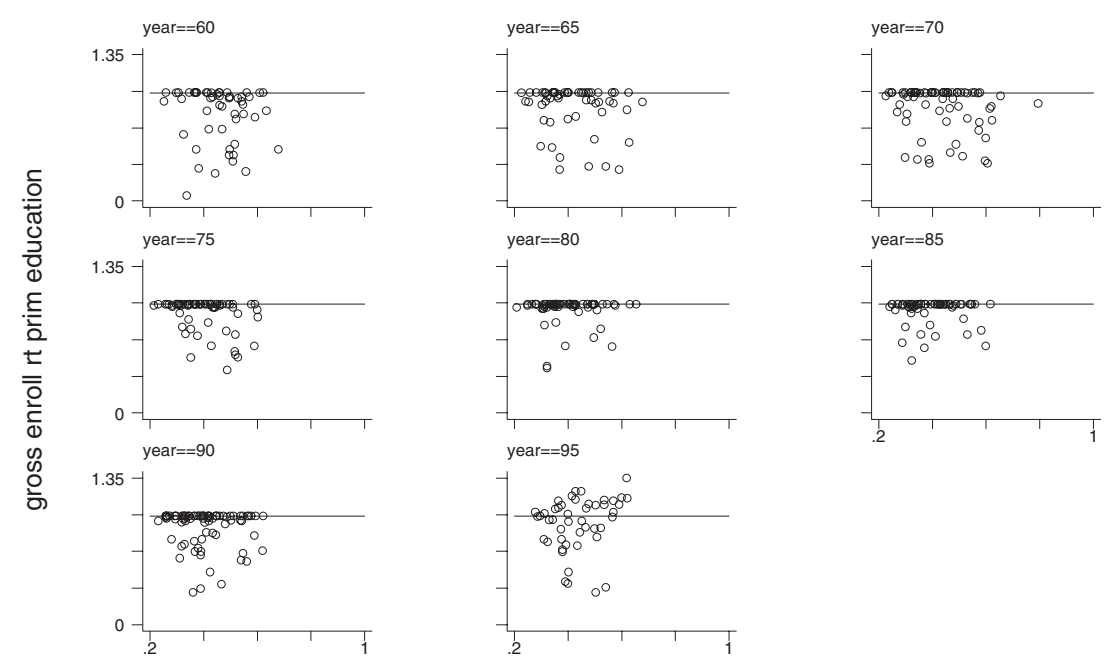

All countries by year - primary education

Figure 3. Income inequality and education — secondary education
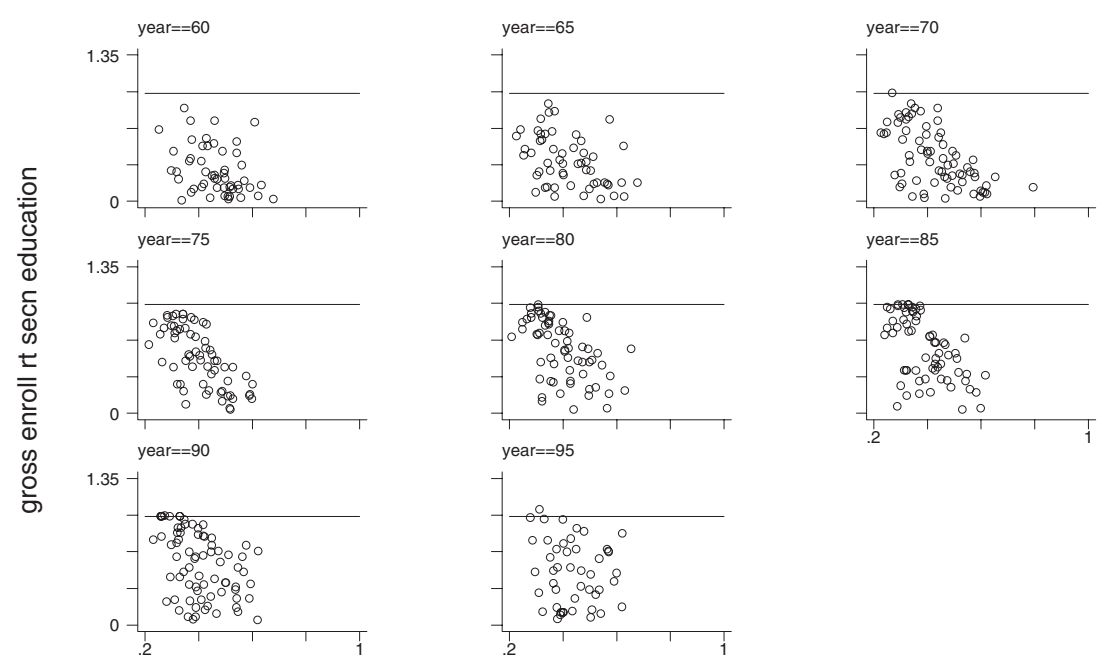

All countries by year - secondary education

(C) CEIS, Fondazione Giacomo Brodolini and Blackwell Publishers Ltd 2003. 
Figure 4. Income inequality and education - tertiary education

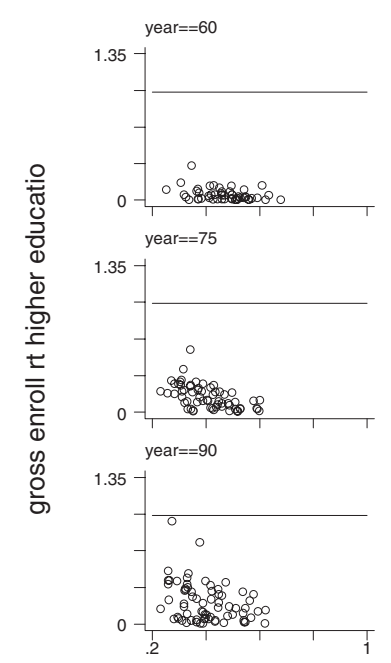

All countries by year - higher education
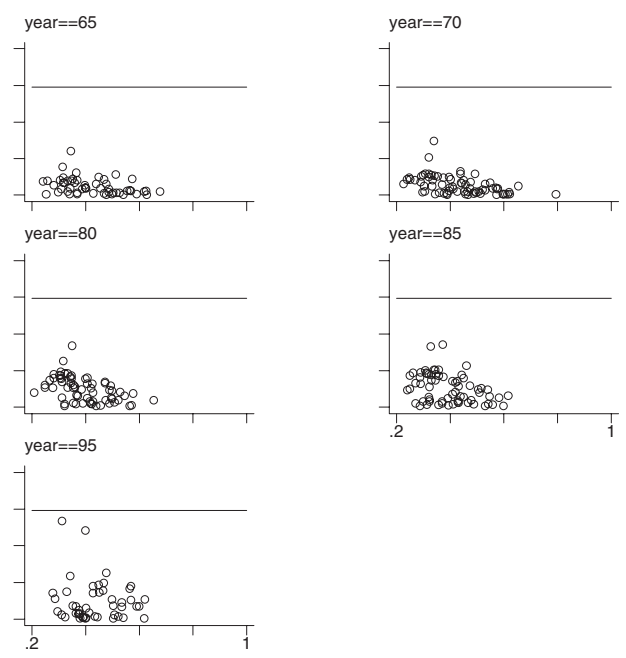

about state spending, employed teachers and repetition rate is available; on the demand side, beyond information about income distribution, we will consider demographic factors (birth rates), family composition (fertility rates) and socio-cultural environment (proxied here by the mortality rates). Given that schooling is a stage-by-stage process (one cannot enrol at university unless one has completed secondary school), educational achievement at a certain stage is conditioned by the achievement obtained at the previous stage (what we term the 'ratchet effect'): given the absence of detailed information on schooling flows, we will proxy this effect with the average achievement of the entire population for that level of education. ${ }^{25}$ Finally, we will control for the stage of development by conditioning on the level of real GNP per capita.

\subsection{Primary education}

Full enrolment for primary education has been almost completely achieved by all countries, especially in recent years. The public push towards attending compulsory education has lowered any cost barrier to accessing education, at least at this stage. We do not find 
evidence of any negative effect of income distribution (as measured by Gini indices) on gross enrolment for primary education. ${ }^{26}$ However, since the same Gini index can be associated with different Lorenz curves, we have also experimented with the income share accruing to the poorest segment of the population, the lowest quintile. In this case, the variable is statistically weakly significant. Columns 1-4 of Table 2 report the country fixed-effects OLS regres-

Table 2. Estimation of primary education enrolment - fixed effects, 1960-95

\begin{tabular}{|c|c|c|c|c|}
\hline \multirow{2}{*}{$\begin{array}{l}\text { Dependent variable: gross enrolment } \\
\text { rate in primary education }\end{array}$} & \multicolumn{4}{|c|}{ Estimated coefficients } \\
\hline & Total & Total & Total & Female \\
\hline Gini index of income distribution & $\begin{array}{c}0.02 \\
(0.33)\end{array}$ & $\begin{array}{l}-0.20 \\
(1.34)\end{array}$ & - & $\begin{array}{l}-0.11 \\
(1.35)\end{array}$ \\
\hline $\begin{array}{l}\text { Income share of the lowest quintile } \\
\text { in income distribution }\end{array}$ & - & $\begin{array}{l}-0.57 \\
(1.06)\end{array}$ & - & - \\
\hline (Log of) real GDP per capita & $\begin{array}{c}0.04 \\
(2.20)\end{array}$ & $\begin{array}{r}0.05 \\
(3.08)\end{array}$ & - & $\begin{array}{c}0.04 \\
(2.05)\end{array}$ \\
\hline $\begin{array}{l}\text { (Log of) inequality-adjusted real } \\
\text { GNP per capita }\end{array}$ & - & - & $\begin{array}{c}0.03 \\
(1.86)\end{array}$ & - \\
\hline $\begin{array}{l}\text { Child mortality rate in the first } \\
\text { year (per } 1,000 \text { births) }\end{array}$ & $\begin{array}{l}-2.48 \\
(8.05)\end{array}$ & $\begin{array}{l}-2.13 \\
(7.57)\end{array}$ & $\begin{array}{l}-2.49 \\
(8.09)\end{array}$ & $\begin{array}{l}-3.14 \\
(8.98)\end{array}$ \\
\hline $\begin{array}{l}\text { Fertility rate (potential children } \\
\text { per woman) }\end{array}$ & $\begin{array}{c}0.08 \\
(7.30)\end{array}$ & $\begin{array}{c}0.06 \\
(6.21)\end{array}$ & $\begin{array}{c}0.07 \\
(7.24)\end{array}$ & $\begin{array}{c}0.08 \\
(7.29)\end{array}$ \\
\hline $\begin{array}{l}\text { Crude birth rate (per } 1,000 \\
\text { inhabitants) }\end{array}$ & $\begin{array}{l}-0.01 \\
(5.78)\end{array}$ & $\begin{array}{l}-0.01 \\
(5.75)\end{array}$ & $\begin{array}{l}-0.01 \\
(5.76)\end{array}$ & $\begin{array}{l}-0.01 \\
(5.00)\end{array}$ \\
\hline $\begin{array}{l}\text { Share of the corresponding } \\
\text { population over } 15 \text { with some } \\
\text { primary education }\end{array}$ & $\begin{array}{l}0.014 \\
(0.29)\end{array}$ & $\begin{array}{l}0.011 \\
(0.24)\end{array}$ & $\begin{array}{l}0.016 \\
(0.32)\end{array}$ & $\begin{array}{c}0.12 \\
(2.14)\end{array}$ \\
\hline $\begin{array}{l}\text { Students per teacher in primary } \\
\text { education }\end{array}$ & $\begin{array}{l}0.002 \\
(2.57)\end{array}$ & $\begin{array}{l}0.003 \\
(3.46)\end{array}$ & $\begin{array}{l}0.002 \\
(2.50)\end{array}$ & $\begin{array}{l}0.001 \\
(1.80)\end{array}$ \\
\hline Constant & $\begin{array}{c}0.59 \\
(3.31)\end{array}$ & $\begin{array}{c}0.60 \\
(3.16)\end{array}$ & $\begin{array}{c}0.71 \\
(4.65)\end{array}$ & $\begin{array}{c}0.55 \\
(2.70)\end{array}$ \\
\hline $\begin{array}{l}\text { No. of observations/No. of } \\
\text { countries }\end{array}$ & $436 / 92$ & $303 / 84$ & $436 / 92$ & $424 / 92$ \\
\hline $\begin{array}{l}\text { Correlation between random } \\
\text { component and individual } \\
\text { explanatory variables }\end{array}$ & 0.09 & 0.03 & 0.10 & 0.15 \\
\hline$R^{2}$ overall & 0.54 & 0.50 & 0.52 & 0.62 \\
\hline$R^{2}$ within & 0.43 & 0.51 & 0.43 & 0.46 \\
\hline$F$-test & $\begin{array}{c}36.34 \\
(0.00)\end{array}$ & $\begin{array}{l}28.10 \\
(0.00)\end{array}$ & $\begin{array}{l}42.11 \\
(0.00)\end{array}$ & $\begin{array}{l}40.69 \\
(0.00)\end{array}$ \\
\hline
\end{tabular}

Note: $t$-statistics in parentheses.

(C) CEIS, Fondazione Giacomo Brodolini and Blackwell Publishers Ltd 2003. 
sions. ${ }^{27}$ However, a negative correlation still exists for the female component of the student population: column 4 of Table 2 reestimates column 1 by restricting consideration to female primary enrolment, and again we find a weakly negative significant impact of income distribution. This could be taken as evidence that expansion of compulsory education has benefited mainly boys, irrespective of the availability of financial resources from the family. Since we do not have good reason to believe that talent is unequally distributed according to gender, we consider this result as the first piece of evidence in favour of the borrowing-constraints interpretation of the negative correlation between Gini index and enrolment rates. It is noteworthy that the same effect does not carry over to the random-effects estimation, or in cross-section: ${ }^{28}$ this could imply that there is something that is country specific in this effect. In other words, financial resources still preclude the access to primary education of girls from poor families in some areas of the world. Why families might be more willing to afford educational expenditure for boys than for girls is strongly intertwined with cultural habits. ${ }^{29}$ In effects, when we control for this possibility using random-effects estimation on regional sub-samples, we find that this result is attributable to East-Asian countries and, to a lesser extent, to Latin American ones. Some additional effect of income distribution can be found when looking at mortality rates. If we take child mortality as a proxy for extreme poverty, we find a significant negative impact on enrolment into primary education. ${ }^{30}$

The process of schooling (even at primary level) is obviously related to the stage of development of a country. If we measure this stage with the (real) gross domestic product per capita, effectively we find that primary enrolment is positively associated with its logarithm. But exploiting a suggestion originally advanced by Sen (1976), and subsequently followed by international agencies as a starting point for measuring the degree of human development, ${ }^{31}$ we correct the level of per capita product $Y$ with the contemporaneous Gini concentration index $G$, thus obtaining a measure of 'inequality-adjusted real income' $Y_{\text {adjust }}$ :

$$
Y_{\text {adjust }}=Y \cdot(1-G) \text {. }
$$

Introducing this regressor instead of $\log Y$ and $G$ as separate regressors corresponds (approximately) to imposing an equality restriction on their coefficients obtained in column 1, which cannot be rejected by the data: the restriction 'coefficient $(\log Y)$ 
$=-\operatorname{coefficient}(G)^{\prime}$ in column 1 of Table 2 has an $F$-test value of $(1,337)=0.70(p=0.40)$. Notice that when using the logarithm of $Y_{\text {adjust }}$ a 1 per cent increase in $Y$ is (approximately) equivalent to a 1-point reduction in the Gini index. The variable $Y_{\text {adjust }}$ comes out highly significant, with a rather low semi-elasticity of 0.03 (column 3 of Table 2); it implies that in order to obtain an increase in primary enrolment of 1 per cent one would require an increase in per capita income of 33 per cent, maintaining the inequality in income distribution constant. All the other variables retain their previous signs and significance.

On the supply side, one finds evidence of a negative impact of population growth (as measured by the crude birth rate), because it necessarily implies a decline of per child resources. It is also true that, for many countries, the limited resources available may prevent school attendance. ${ }^{32}$ This could explain the rather counterintuitive result of the number of students per teacher exhibiting a significant and positive impact (instead of a negative one, as one would have expected when thinking of greater resources and better quality being associated with lower values of this variable). In other words, a greater number of students per teacher would indicate a country's effort to catch up with full attendance in primary education. $^{33}$

On the demand side, family background seems to account for some variation. If we take the fertility rate $\mathrm{e}^{34}$ as proportional to the average number of children in a family, we could expect either negative or positive effects. The former case applies when resources are binding - the greater the number of children in a family, the lower the resources per capita, and the greater the opportunity cost of school attendance. Contrariwise, the latter case applies when supportive effects could be accounted for; in this case, the larger the number of siblings, the higher the probability that someone else has already had some schooling experience, and therefore the greater the chance of getting some help at home. ${ }^{35}$ The relevance of the cultural environment (the so-called social capital) is also witnessed by the positive effect played by the stock of people with some (but incomplete) primary education. The positive effect could be explained on two grounds. On one side, some of the population (older than 15 years) with uncompleted primary education could re-enrol into primary education, thus raising the gross rate of enrolment. On the other side, it may be correlated with the effort of a country to overcome illiteracy, and therefore it describes the pressure put on children to enrol and complete primary education. ${ }^{36}$ 
We were unable to find strong effects of public resources invested in education on enrolment. Using a subset of countries for which educational resources information is available, a richer specification does not provide any improvement on previous results. While income inequality remains insignificant, all the proxies used to capture different aspects of publicly invested resources tend to be insignificant. Additional resources invested in education can take different forms: fewer students per teacher, better-paid teachers, a greater ratio of governmental current expenditure on primary education per pupil on per capita GDP (or simply a greater share of education expenditure on GDP), and a greater share of educational resources invested in buildings and equipment. Or we could even look at more care devoted to attending children, negatively proxied by drop-out and repetition rates. In accordance with the previous model, we expect that an increase in public resources ceteris paribus should facilitate school attendance, and therefore increase school enrolment. In all these cases, with the exception of teachers' pay and drop-out rates, we do not find strong evidence of positive effects of more resources on primary enrolment. The case of drop-out rate could be due to different regional patterns. ${ }^{37}$ The case of teachers' pay is inconclusive: for given resources, having better-paid teachers necessarily implies having fewer teachers, fewer or more crowded classes, and consequently less availability in terms of educational service. This is, for example, the explanation advanced by Ridker (1994) for the decline in primary enrolment for sub-Saharan Africa in the last decade. ${ }^{38}$

\subsection{Secondary education}

When considering secondary education, we find a strong correlation between income distribution and school enrolment. The Gini index comes out significantly negative: a 1-point decline in the index (more equalitarian distribution) implies a 0.25 per cent rise in secondary enrolment (column 1 of Table 3 ). The same effect is obtained when considering inequality-adjusted real income $Y_{\text {adjust }}$, with a somehow lower impact (column 3 of Table 3 ). ${ }^{39}$ Also in this case we find additional evidence of possible discrimination against girls: a significant increase in inequality (say a $\Delta$ Gini of +0.05 ) reduces secondary school enrolment to 1 per cent for boys and 1.8 per cent for girls. ${ }^{40}$ Notice, in addition, that the coefficient measuring the impact of inequality for girls is larger than in the case of primary school $(-0.35$ against -0.11$)$, and this suggests that finan- 
Table 3. Estimation of secondary education enrolment - fixed effects, 1960-95

\begin{tabular}{lcccc}
\hline & \multicolumn{4}{c}{ Estimated coefficients } \\
\cline { 2 - 5 } $\begin{array}{l}\text { Dependent variable: gross enrolment } \\
\text { rate in primary education }\end{array}$ & Total & Total & Total & Female \\
\hline Gini index of income distribution & -0.24 & 0.01 & - & -0.35 \\
& $(2.68)$ & $(0.06)$ & & $(3.73)$ \\
Income share of the lowest quintile & - & 0.69 & - & - \\
$\quad$ in income distribution & & $(0.88)$ & & 0.15 \\
(Log of) real GDP per capita & 0.14 & 0.15 & - & $(6.37)$ \\
& $(6.37)$ & $(6.03)$ & & - \\
(Log of) inequality-adjusted real & - & - & $(7.17)$ & \\
$\quad$ GNP per capita & & & -0.05 & -0.06 \\
Fertility rate (potential children & -0.05 & -0.06 & $(5.34)$ & $(6.03)$ \\
$\quad$ per woman) & $(5.33)$ & $(5.62)$ & 0.06 & 0.06 \\
Average years of completed & 0.06 & 0.04 & 0.06 \\
$\quad$ primary education in the & $(6.15)$ & $(3.42)$ & $(6.10)$ & $(5.20)$ \\
$\quad$ corresponding population over 15 & & & & \\
Ratio of physical capital stock to & 0.04 & 0.05 & 0.04 & 0.05 \\
$\quad$ GDP (1987 local prices) & $(3.26)$ & $(3.40)$ & $(3.56)$ & $(3.81)$ \\
Constant & -0.67 & -0.82 & -0.67 & -0.65 \\
& $(3.31)$ & $(3.05)$ & $(3.93)$ & $(3.07)$ \\
No. of observations/No. of & $386 / 76$ & $264 / 69$ & $386 / 76$ & $369 / 76$ \\
$\quad$ countries & & & & \\
Correlation between random & -0.65 & -0.58 & -0.64 & -0.73 \\
$\quad$ component and individual & & & & \\
$\quad$ explanatory variables & & & & \\
$R^{2}$ overall & 0.79 & 0.76 & 0.79 & 0.82 \\
$R^{2}$ within & 0.65 & 0.68 & 0.65 & 0.69 \\
$F$-test & 115.1 & 67.27 & 143.3 & 127.7 \\
& $(0.00)$ & $(0.00)$ & $(0.00)$ & $(0.00)$ \\
\hline
\end{tabular}

Note: $t$-statistics in parentheses.

cial constraints are more relevant at this stage of education. It is interesting also to note that liquidity constraints seem to affect the whole span of income distribution, since the coefficient of the income share of the lowest quintile is not significantly different from $0{ }^{41}$

On the demand side we find evidence of some effect in terms of family composition, as proxied by the fertility rate. While this variable exhibits a positive effect at primary level (and was explained there as evidence of the effort of a supportive effect within the family), in this case it presents a clearly negative impact, which can 
be interpreted as evidence of a family resource effect. If we consider that sending a child to a secondary school (which in most countries exceeds the threshold of compulsory education) is a more demanding task (at least on the financial side), an increase in family size implies a reduction in resources per child (in terms both of income, partially captured by the inequality and output per capita variables, and time devoted to children by the parents).

On the supply side we find weak effects of resources invested in education; the number of pupils per teacher, the ratio of governmental current expenditure on secondary education per pupil on GDP per capita, the repetition rate, the aggregate expenditure on education (as a share on GDP) and its composition; all variables exert a statistically insignificant effect (columns 2 and 5 in Table 4). ${ }^{42}$ However, when we interact data for public expenditure on education with the Gini index on income distribution, we find that their impact becomes significant: an increase in public resources devoted to current expenditure on education raises secondary enrolment, especially for countries with very unequal income distribution. ${ }^{43}$ The Gini index remains negatively significant; in addition, when we take the total derivative of secondary enrolment with respect to the Gini index from the third column we get:

$$
\begin{aligned}
\frac{\delta \text { enrolment }}{\delta \text { Gini index }}= & -2.11+28.86(\text { educ. exp./GDP }) \\
& +2.33 \text { (capital exp./total exp.) }
\end{aligned}
$$

which evaluated at sample means is equal to -0.49 . We take this result as a second piece of evidence in support of a liquidity constraint interpretation of the relationship between income distribution and school enrolment. Had this relationship been attributable to talent transmission, we would have expected the opposite result. Since more talented students take more advantage of greater resources invested in education, ${ }^{44}$ we should find that an increase in public expenditure widens the dispersion of educational achievements and, ceteris paribus, strengthens the relationship between secondary enrolment and the Gini index of income distribution. Contrariwise, if the relationship is attributable to liquidity constraints, an increase in public expenditure lowers the barriers to access, and weakens the same relationship; this is what we infer from equation [16]. In other words, public resources do not have a direct impact, but they are effective in easing family choices in 
Table 4. Estimation of secondary education enrolment using different variables for educational resources — fixed effects, 1960-95

\begin{tabular}{|c|c|c|c|c|c|c|}
\hline \multirow{2}{*}{$\begin{array}{l}\text { Dependent variable: gross } \\
\text { enrolment rate } \\
\text { in secondary education }\end{array}$} & \multicolumn{6}{|c|}{ Estimated coefficients } \\
\hline & Total & Total & Total & Female & Female & Female \\
\hline $\begin{array}{l}\text { Gini index of income } \\
\text { distribution }\end{array}$ & $\begin{array}{l}-0.38 \\
(2.71)\end{array}$ & $\begin{array}{l}-0.33 \\
(2.18)\end{array}$ & $\begin{array}{l}-2.11 \\
(4.68)\end{array}$ & $\begin{array}{l}-0.40 \\
(2.66)\end{array}$ & $\begin{array}{l}-0.35 \\
(2.20)\end{array}$ & $\begin{array}{l}-2.44 \\
(5.17)\end{array}$ \\
\hline $\begin{array}{l}\text { (Log of) real GDP per } \\
\text { capita }\end{array}$ & $\begin{array}{c}0.20 \\
(5.44)\end{array}$ & $\begin{array}{c}0.20 \\
(5.00)\end{array}$ & $\begin{array}{c}0.15 \\
(4.13)\end{array}$ & $\begin{array}{c}0.21 \\
(5.13)\end{array}$ & $\begin{array}{c}0.19 \\
(4.44)\end{array}$ & $\begin{array}{c}0.14 \\
(3.37)\end{array}$ \\
\hline $\begin{array}{l}\text { Fertility rate (potential } \\
\text { children per woman) }\end{array}$ & $\begin{array}{l}-0.03 \\
(2.27)\end{array}$ & $\begin{array}{l}-0.03 \\
(1.82)\end{array}$ & $\begin{array}{l}-0.03 \\
(1.87)\end{array}$ & $\begin{array}{l}-0.03 \\
(1.92)\end{array}$ & $\begin{array}{l}-0.03 \\
(1.65)\end{array}$ & $\begin{array}{l}-0.03 \\
(1.79)\end{array}$ \\
\hline $\begin{array}{l}\text { Average years of completed } \\
\text { primary education in } \\
\text { the corresponding } \\
\text { population over } 15\end{array}$ & $\begin{array}{c}0.07 \\
(3.25)\end{array}$ & $\begin{array}{c}0.07 \\
(2.85)\end{array}$ & $\begin{array}{c}0.10 \\
(4.04)\end{array}$ & $\begin{array}{c}0.09 \\
(3.47)\end{array}$ & $\begin{array}{c}0.09 \\
(3.13)\end{array}$ & $\begin{array}{c}0.13 \\
(4.63)\end{array}$ \\
\hline $\begin{array}{l}\text { Ratio of physical capital } \\
\text { stock to GDP (1987 } \\
\text { local prices) }\end{array}$ & $\begin{array}{c}0.04 \\
(1.74)\end{array}$ & $\begin{array}{c}0.04 \\
(1.74)\end{array}$ & $\begin{array}{c}0.04 \\
(1.78)\end{array}$ & $\begin{array}{c}0.04 \\
(1.89)\end{array}$ & $\begin{array}{c}0.04 \\
(1.69)\end{array}$ & $\begin{array}{c}0.03 \\
(1.58)\end{array}$ \\
\hline $\begin{array}{l}\text { Students per teacher in } \\
\text { secondary education }\end{array}$ & - & $\begin{array}{l}0.001 \\
(0.40)\end{array}$ & $\begin{array}{l}0.002 \\
(1.02)\end{array}$ & - & $\begin{array}{l}0.0001 \\
(0.03)\end{array}$ & $\begin{array}{l}0.001 \\
(0.73)\end{array}$ \\
\hline $\begin{array}{l}\text { Repetition rate - } \\
\text { secondary education }\end{array}$ & - & $\begin{array}{l}0.001 \\
(0.68)\end{array}$ & $\begin{array}{c}0.02 \\
(1.42)\end{array}$ & - & $\begin{array}{l}0.001 \\
(0.75)\end{array}$ & $\begin{array}{l}0.003 \\
(1.59)\end{array}$ \\
\hline $\begin{array}{l}\text { Per pupil government } \\
\text { expenditure on } \\
\text { secondary education/ } \\
\text { GDP per capita }\end{array}$ & - & $\begin{array}{l}-0.001 \\
(1.19)\end{array}$ & $\begin{array}{c}-0.001 \\
(1.25)\end{array}$ & - & $\begin{array}{l}-0.0007 \\
(0.70)\end{array}$ & $\begin{array}{r}-0.001 \\
(0.77)\end{array}$ \\
\hline $\begin{array}{l}\text { Government expenditure } \\
\text { on education/GDP }\end{array}$ & - & $\begin{array}{l}-0.08 \\
(0.09)\end{array}$ & $\begin{array}{c}-10.70 \\
(3.80)\end{array}$ & - & $\begin{array}{c}0.28 \\
(0.29)\end{array}$ & $\begin{array}{r}-11.19 \\
(3.80)\end{array}$ \\
\hline $\begin{array}{l}\text { (Government expenditure } \\
\text { on education/GDP) } \times \\
\text { Gini index }\end{array}$ & - & - & $\begin{array}{l}28.86 \\
(4.00)\end{array}$ & - & - & 31.9 \\
\hline $\begin{array}{l}\text { Capital expenditure/total } \\
\text { government expenditure } \\
\text { on education }\end{array}$ & - & $\begin{array}{l}-0.23 \\
(1.64)\end{array}$ & $\begin{array}{l}-1.11 \\
(2.28)\end{array}$ & - & $\begin{array}{l}-0.30 \\
(2.02)\end{array}$ & $\begin{array}{l}-1.79 \\
(3.48)\end{array}$ \\
\hline $\begin{array}{l}\text { (Capital expenditure/total } \\
\text { government expenditure } \\
\text { on education) } \times \text { Gini index }\end{array}$ & - & - & $\begin{array}{c}2.33 \\
(1.99)\end{array}$ & - & - & $\begin{array}{c}3.89 \\
(3.13)\end{array}$ \\
\hline Constant & Yes & Yes & Yes & Yes & Yes & Yes \\
\hline $\begin{array}{l}\text { No. of observations/No. } \\
\text { of countries }\end{array}$ & $133 / 50$ & $133 / 50$ & $133 / 50$ & $130 / 49$ & $130 / 49$ & $130 / 49$ \\
\hline $\begin{array}{l}\text { Correlation between } \\
\text { random component } \\
\text { and individual } \\
\text { explanatory variables }\end{array}$ & -0.75 & -0.71 & -0.71 & -0.82 & -0.80 & -0.80 \\
\hline$R^{2}$ overall & 0.77 & 0.77 & 0.78 & 0.83 & 0.82 & 0.82 \\
\hline$R^{2}$ within & 0.76 & 0.77 & 0.82 & 0.77 & 0.79 & 0.84 \\
\hline$F$-test & $\begin{array}{c}49.0 \\
(0.00)\end{array}$ & $\begin{array}{l}25.1 \\
(0.00)\end{array}$ & $\begin{array}{c}26.7 \\
(0.00)\end{array}$ & $\begin{array}{c}52.9 \\
(0.00)\end{array}$ & $\begin{array}{l}27.2 \\
(0.00)\end{array}$ & $\begin{array}{l}31.1 \\
(0.00)\end{array}$ \\
\hline
\end{tabular}

Note: $t$-statistics in parentheses. 
relation to letting their children proceed further in their educational career.

Another aspect related to the public supply of secondary education has to do with the 'vertical integration' of this process; if we consider that a student can enrol in a secondary school only if s/he has completed the primary level, evidently an increase in the completion of primary education provides additional inputs to the next stage of production. This 'ratchet effect' makes it rather implausible to observe enrolment rates at higher stages greater than those observed at lower stages. Effectively, we find that the average number of years of completed primary education in the population $^{45}$ play a significant positive effect; raising the sample mean (3.94 years) by an additional year should induce an increase in secondary enrolment in the order of 4-6 percentage points, depending on the chosen specification. Family choices also seem to respond to the existing situation in the labour market, probably via differential returns for education and/or differential employment probability. ${ }^{46}$ Under the assumption of complementarities between human and physical capital in production, ${ }^{47}$ we can approximate the skill requirement in the economy with existing capital intensity (the ratio of physical capital to output). In such a case, we observe that an increase in demand for skills in the labour market (i.e. an increase in capital/output ratio) induces an increase in secondary school enrolment. However, the size of the effect is not very great; a 10 per cent increase in capital/output ratio (from an average of 2.58 to 2.84 ) would raise secondary enrolment just 0.4 per cent. ${ }^{48}$

\subsection{Higher education}

Moving finally to higher education, as found in the case of primary education we find weak evidence of direct impact of either income inequality or first quintile shares on higher education enrolment (columns 1 and 2 in Table 5). ${ }^{49}$ Given the fact that many authors stress that public finance of tertiary education has a regressive effect because the offspring of the middle classes are overrepresented, we have also tested the possible existence of liquidity constraints within this group by using the income share of each quintile (taken either separately or jointly), but we could not detect any statistically significant effect. When we make use of the inequality-adjusted real income $Y_{\text {adjust }}$, the variable is significant but the result is driven mainly by the underlying effect of output per 
Table 5. Estimation of higher education enrolment - fixed effects, 1960-95

\begin{tabular}{|c|c|c|c|c|c|}
\hline \multirow{2}{*}{$\begin{array}{l}\text { Dependent variable: gross enrolment } \\
\text { rate in higher education }\end{array}$} & \multicolumn{5}{|c|}{ Estimated coefficients } \\
\hline & Total & Total & Total & Female & Male \\
\hline Gini index of income distribution & $\begin{array}{l}-0.07 \\
(0.92)\end{array}$ & $\begin{array}{c}0.14 \\
(0.68)\end{array}$ & - & $\begin{array}{l}-0.07 \\
(1.05)\end{array}$ & $\begin{array}{l}-0.13 \\
(2.10)\end{array}$ \\
\hline $\begin{array}{l}\text { Income share of the lowest quintile } \\
\text { in income distribution }\end{array}$ & - & $\begin{array}{c}0.61 \\
(0.83)\end{array}$ & - & - & - \\
\hline (Log of) real GDP per capita & $\begin{array}{c}0.08 \\
(3.91)\end{array}$ & $\begin{array}{c}0.14 \\
(4.11)\end{array}$ & - & $\begin{array}{c}0.04 \\
(2.24)\end{array}$ & $\begin{array}{c}0.08 \\
(4.07)\end{array}$ \\
\hline $\begin{array}{l}\text { (Log of) inequality-adjusted real } \\
\text { GNP per capita }\end{array}$ & - & - & $\begin{array}{c}0.07 \\
(3.97)\end{array}$ & - & - \\
\hline $\begin{array}{l}\text { (Log of) government current } \\
\text { expenditure in secondary } \\
\text { education per pupil (PPP- } \\
\text { adjusted } 1985 \text { intn. prices) }\end{array}$ & $\begin{array}{c}0.02 \\
(2.13)\end{array}$ & $\begin{array}{c}0.02 \\
(1.51)\end{array}$ & $\begin{array}{c}0.02 \\
(2.52)\end{array}$ & $\begin{array}{c}0.03 \\
(2.87)\end{array}$ & $\begin{array}{c}0.01 \\
(0.77)\end{array}$ \\
\hline $\begin{array}{l}\text { Average years of completed } \\
\text { secondary education in the } \\
\text { corresponding population over } 15\end{array}$ & $\begin{array}{c}0.07 \\
(5.88)\end{array}$ & $\begin{array}{c}0.04 \\
(2.74)\end{array}$ & $\begin{array}{c}0.07 \\
(5.97)\end{array}$ & $\begin{array}{c}0.08 \\
(7.22)\end{array}$ & $\begin{array}{c}0.05 \\
(4.88)\end{array}$ \\
\hline $\begin{array}{l}\text { Ratio of physical capital stock to } \\
\text { GDP (1987 local prices) }\end{array}$ & $\begin{array}{c}0.01 \\
(1.06)\end{array}$ & $\begin{array}{c}0.02 \\
(1.01)\end{array}$ & $\begin{array}{c}0.01 \\
(1.45)\end{array}$ & $\begin{array}{c}0.01 \\
(0.71)\end{array}$ & $\begin{array}{c}0.02 \\
(2.57)\end{array}$ \\
\hline Constant & $\begin{array}{l}-0.76 \\
(5.08)\end{array}$ & $\begin{array}{l}-1.39 \\
(4.94)\end{array}$ & $\begin{array}{l}-0.67 \\
(5.83)\end{array}$ & $\begin{array}{l}-0.51 \\
(3.76)\end{array}$ & $\begin{array}{l}-0.60 \\
(4.51)\end{array}$ \\
\hline No. of observations/No. of countries & $303 / 72$ & $210 / 65$ & $303 / 72$ & $254 / 70$ & $253 / 69$ \\
\hline $\begin{array}{l}\text { Correlation between random } \\
\text { component and individual } \\
\text { explanatory variables }\end{array}$ & -0.59 & -0.68 & -0.55 & -0.59 & -0.39 \\
\hline$R^{2}$ overall & 0.63 & 0.57 & 0.63 & 0.59 & 0.60 \\
\hline$R^{2}$ within & 0.57 & 0.57 & 0.57 & 0.60 & 0.61 \\
\hline$F$-test & $\begin{array}{l}60.22 \\
(0.00)\end{array}$ & $\begin{array}{l}31.47 \\
(0.00)\end{array}$ & $\begin{array}{c}74.9 \\
(0.00)\end{array}$ & $\begin{array}{l}54.63 \\
(0.00)\end{array}$ & $\begin{array}{l}55.51 \\
(0.00)\end{array}$ \\
\hline
\end{tabular}

Note: $t$-statistics in parentheses.

capita. ${ }^{50}$ More surprising is the result that income inequality seems to affect male enrolment more than female enrolment. The differences in sample averages between the enrolment rates of the two genders are not very pronounced (16.2 per cent for men against 11.4 per cent for women), and therefore we cannot explain it with a composition effect. The talent transmission explanation cannot account for this difference, unless we pursue a self-selectivity explanation: males and females have different preferences, and the latter withdraw from education more frequently than the former. But we 
believe that a more realistic explanation lies in the fact that the daughters from financially constrained families have already abandoned school at earlier stages, and therefore the 11 per cent actually enrolled in school belong to rich families. Contrariwise, since financial constraints restrain male enrolment starting only from secondary level, the selection according to family resources has operated less strongly among them, and we can still find sons from middle-class families that are financially constrained when asked to pay for enrolment at university. In our opinion this is a third piece of evidence supporting the liquidity constraints line of interpretation.

As far as the supply of higher education is concerned, there is evidence of a positive effect of public expenditure per pupil at the previous stage. If we take this variable as a proxy of the quality of education provided at secondary school, this evidence suggests that increasing the resources invested at one stage of education can be ineffective in directly raising student participation at that level, but can be beneficial in favouring the transition to the next stage (e.g. by raising the self-confidence of the students). This impact is rather low; a 10 per cent increase in public expenditure per student enrolled in secondary school (equal to US\$103 measured at 1985 prices) induces an increase of 0.21 percentage points in higher education enrolment. The ratchet effect (namely the interdependence between sequential stages of education) emerges also through the positive effect exerted by the average years of secondary education achieved in the population aged over 15 years; an additional year (from a sample average of 1.4 years) induces an increase of almost 50 per cent in higher education enrolment. ${ }^{51}$ When considering alternative measures relating to educational resources, we find only a significantly positive effect of the total amount of public resources invested in education on higher education enrolment. Other direct measures of invested resources (such as students per teacher) do not have direct information about the resources invested at this stage of education. ${ }^{52}$ On the demand side, the only evidence comes from the demand for skilled workers, as proxied by the capital/output ratio. Even if the coefficient is lower than in the case of secondary education, the elasticities are of comparable magnitude (see Table 6). This is might indicate that the productive sector requires more technical training (provided mostly by secondary schools) than professional credentials provided by universities. Notice, moreover, that the effect of this variable is significantly higher for men than for women. 
Table 6. Elasticities of enrolment at different educational levels

\begin{tabular}{|c|c|c|c|}
\hline & Primary & Secondary & Higher \\
\hline $\begin{array}{l}\text { Gini index of income distribution } \\
\text { (column } 1 \text { in Tables } 2,3,5)\end{array}$ & -0.011 & $-0.211^{* *}$ & -0.185 \\
\hline $\begin{array}{l}\text { (Log of) inequality-adjusted real GNP } \\
\text { per capita (column } 3 \text { in Tables } 2,3,5 \text { ) }\end{array}$ & $0.033^{*}$ & $0.281 * *$ & $0.529 * *$ \\
\hline $\begin{array}{l}\text { Average years of completed education at } \\
\text { previous stage (column } 1 \text { in Tables } 2,3,5 \text { ) }\end{array}$ & $0.006^{* *}$ & $0.520 * *$ & $0.622 * *$ \\
\hline $\begin{array}{l}\text { Ratio of physical capital stock to GDP } \\
\text { (column } 1 \text { in Tables } 2,3,5)\end{array}$ & - & $0.215^{* *}$ & 0.194 \\
\hline Female only: & & & \\
\hline $\begin{array}{l}\text { Gini index of income distribution } \\
\quad(\text { column } 4 \text { in Tables } 2,3,5)\end{array}$ & -0.054 & $-0.311 * *$ & -0.260 \\
\hline $\begin{array}{l}\text { Average years of completed education at } \\
\text { previous stage (column } 4 \text { in Tables } 2,3,5 \text { ) }\end{array}$ & $0.060^{*}$ & $0.467 * *$ & $0.907^{* *}$ \\
\hline
\end{tabular}

Notes: * Statistically significant at 95 per cent; ** statistically significant at 99 per cent.

\section{Concluding remarks}

In this paper we have examined some empirical evidence in support of the negative correlation between inequality and growth. Starting from a general model of optimal demand for education, we have argued that the dependence on family income may derive either from talent transmission or from borrowing constraints with imperfect financial markets. In both cases, if family incomes are log-linearly distributed, we derive two testable predictions in the analysis of aggregate data on school enrolments: a negative (linear) dependence on the Gini concentration index on income distribution; and a positive dependence on public resources invested in education and/or on skill premiums in the labour market. These predictions are then tested on a (unbalanced) panel of 108 countries for the period 1960-95.

The main findings of this analysis are summarized in Table 6. Once we control for the degree of development with the (log of) per capita output, income inequality seems relevant mainly in limiting the access to secondary education. However, when we consider gender differences, there is evidence that female participation in education is more strongly conditioned by family income, starting from primary education. Contrariwise, there is no clear evidence of a relevant impact in terms of invested resources, except at the tertiary 
level. Some positive effect is also played by labour demand for skilled workers, which tends to raise enrolment in post-primary education. Other conditioning variables, at primary and secondary level, are fertility rates and mortality rates, which tend to capture other aspects of social development. Finally, the data show that increasing education at one stage raises the odds for subsequent stages. ${ }^{53}$

When we come to the interpretation of these results, we have argued that there is clear evidence in favour of a borrowing constraint interpretation against a talent transmission reading. First, we found differential effects of income inequality on male and female enrolment rates. While still compatible with a differences-inpreferences story, we believe that this is the reflection of family behaviours: with scarce financial resources, traditionally families invest more readily in boys' than in girls' education. Second, we found that public resources affect secondary enrolment when interacted with income inequality. We take this as evidence of public expenditure on education alleviating family liquidity constraints. The opposite reading, where the brightest children are the offspring of the richest families, cannot account for these two facts. ${ }^{54}$

Provided our reading based on borrowing constraints is accepted, income redistribution should matter for educational goals. The size of the effect is not impressive: lowering the Gini index by 5 percentage points, a sizeable change at sample means, produces a total increase in school participation of almost 2 percentage points. ${ }^{55}$ However, if one is willing to accept the conclusions of the present study, when a country wants to raise the educational level of its population, rather than spending additional resources on building schools and hiring teachers (which, at best, have an indirect effect on secondary school enrolments), it should rather implement redistributive policies (via taxes and/or subsidies). Provided these policies are effective in reducing income inequalities within the population, they are also capable of relaxing the financial constraints faced by the poorest families, and promoting school enrolment. In the light of statistical irrelevance of invested resources in promoting enrolment, any policy recommendation on expenditure reallocation (e.g. from tertiary to primary, or vice versa) seems pointless, given the limited impact of resources on school enrolment. ${ }^{56}$ But a similar argument applies to the idea of expanding a private provider of education. As long as school fees create an additional financial barrier to continuing education, we expect a reduction in total enrolment because it raises financial barriers against financially constrained families. ${ }^{57}$ 


\section{Appendix}

Table A1a. Descriptive statistics — sub-Saharan Africa

\begin{tabular}{|c|c|c|c|c|c|c|}
\hline & $\begin{array}{l}\text { Mean } \\
\text { entire } \\
\text { sample }\end{array}$ & SD & $\begin{array}{c}\text { Mean } \\
\text { year = } 60\end{array}$ & $\begin{array}{c}\text { Mean } \\
\text { year }=70\end{array}$ & $\begin{array}{c}\text { Mean } \\
\text { year }=80\end{array}$ & $\begin{array}{c}\text { Mean } \\
\text { year }=90\end{array}$ \\
\hline $\begin{array}{l}\text { Gross enrolment } \\
\text { rate in primary } \\
\text { education }\end{array}$ & $\begin{array}{l}0.610 \\
(227)\end{array}$ & 0.292 & 0.425 & 0.525 & 0.703 & 0.692 \\
\hline $\begin{array}{l}\text { Gross enrolment } \\
\text { rate in } \\
\text { secondary } \\
\text { education }\end{array}$ & $\begin{array}{l}0.135 \\
(220)\end{array}$ & 0.135 & 0.038 & 0.078 & 0.149 & 0.213 \\
\hline $\begin{array}{l}\text { Gross enrolment } \\
\text { rate in higher } \\
\text { education }\end{array}$ & $\begin{array}{l}0.013 \\
(221)\end{array}$ & 0.019 & 0.002 & 0.007 & 0.013 & 0.025 \\
\hline $\begin{array}{l}\text { Gini index of } \\
\text { income } \\
\text { distribution }\end{array}$ & $\begin{array}{c}0.485 \\
(97)\end{array}$ & 0.098 & 0.517 & 0.540 & 0.485 & 0.456 \\
\hline $\begin{array}{l}\text { Total population } \\
(000 \mathrm{~s})\end{array}$ & $\begin{array}{l}10,221 \\
(240)\end{array}$ & 15,314 & 6,058 & 7,929 & 10,573 & 13,670 \\
\hline $\begin{array}{l}\text { Real GDP per } \\
\text { capita - US } \\
\text { dollars (1985 } \\
\text { international } \\
\text { prices) }\end{array}$ & $\begin{array}{l}1,031.6 \\
(234)\end{array}$ & 918.3 & 806 & 986 & 1,187 & 1,261 \\
\hline
\end{tabular}

Notes: Numbers in parentheses report the number of non-missing observations in each sample (or sub-sample). It includes 30 countries: Botswana, Burkina Faso, Cameroon, Central African Republic, Ethiopia, Gabon, Gambia, Ghana, Guinea, Guinea-Bissau, Côte d'Ivoire, Kenya, Lesotho, Liberia, Madagascar, Malawi, Mali, Mauritania, Mauritius, Niger, Nigeria, Rwanda, Senegal, Sierra Leone, South Africa, Sudan, Tanzania, Uganda, Zambia, and Zimbabwe. 
Table A1b. Descriptive statistics — North Africa and the Middle East

\begin{tabular}{|c|c|c|c|c|c|c|}
\hline & $\begin{array}{l}\text { Mean } \\
\text { entire } \\
\text { sample }\end{array}$ & SD & $\begin{array}{c}\text { Mean } \\
\text { year }=60\end{array}$ & $\begin{array}{c}\text { Mean } \\
\text { year }=70\end{array}$ & $\begin{array}{c}\text { Mean } \\
\text { year }=80\end{array}$ & $\begin{array}{c}\text { Mean } \\
\text { year }=90\end{array}$ \\
\hline $\begin{array}{l}\text { Gross enrolment } \\
\text { rate in primary } \\
\text { education }\end{array}$ & $\begin{array}{c}0.804 \\
(69)\end{array}$ & 0.235 & 0.611 & 0.722 & 0.872 & 0.921 \\
\hline $\begin{array}{l}\text { Gross enrolment } \\
\text { rate in } \\
\text { secondary } \\
\text { education }\end{array}$ & $\begin{array}{c}0.397 \\
(68)\end{array}$ & 0.260 & 0.192 & 0.276 & 0.474 & 0.637 \\
\hline $\begin{array}{l}\text { Gross enrolment } \\
\text { rate in higher } \\
\text { education }\end{array}$ & $\begin{array}{c}0.087 \\
(70)\end{array}$ & 0.092 & 0.021 & 0.045 & 0.111 & 0.136 \\
\hline $\begin{array}{l}\text { Gini index of } \\
\text { income } \\
\text { distribution }\end{array}$ & $\begin{array}{c}0.413 \\
(34)\end{array}$ & 0.073 & 0.472 & 0.436 & 0.404 & 0.376 \\
\hline $\begin{array}{l}\text { Total population } \\
(000 \mathrm{~s})\end{array}$ & $\begin{array}{c}15,210 \\
(72)\end{array}$ & 15,835 & 9,032 & 11,817 & 15,311 & 20,419 \\
\hline $\begin{array}{l}\text { Real GDP per } \\
\text { capita - US } \\
\text { dollars (1985 } \\
\text { international } \\
\text { prices) }\end{array}$ & $\begin{array}{c}2,871.7 \\
(67)\end{array}$ & $2,021.4$ & 1,675 & 2,370 & 3,138 & 3,662 \\
\hline
\end{tabular}

Notes: Numbers in parentheses report the number of non-missing observations in each sample (or sub-sample). It includes nine countries: Algeria, Egypt, Morocco, Tunisia, Iran, Israel, Jordan, North Yemen, and Cyprus. 
Table A1c. Descriptive statistics — East Asia and the Pacific

\begin{tabular}{|c|c|c|c|c|c|c|}
\hline & $\begin{array}{l}\text { Mean } \\
\text { entire } \\
\text { sample }\end{array}$ & SD & $\begin{array}{c}\text { Mean } \\
\text { year }=60\end{array}$ & $\begin{array}{c}\text { Mean } \\
\text { year }=70\end{array}$ & $\begin{array}{c}\text { Mean } \\
\text { year }=80\end{array}$ & $\begin{array}{c}\text { Mean } \\
\text { year }=90\end{array}$ \\
\hline $\begin{array}{l}\text { Gross enrolment } \\
\text { rate in primary } \\
\text { education }\end{array}$ & $\begin{array}{c}0.931 \\
(86)\end{array}$ & 0.147 & 0.853 & 0.908 & 0.960 & 0.964 \\
\hline $\begin{array}{l}\text { Gross enrolment } \\
\text { rate in } \\
\text { secondary } \\
\text { education }\end{array}$ & $\begin{array}{c}0.498 \\
(86)\end{array}$ & 0.279 & 0.258 & 0.420 & 0.583 & 0.606 \\
\hline $\begin{array}{l}\text { Gross enrolment } \\
\text { rate in higher } \\
\text { education }\end{array}$ & $\begin{array}{c}0.123 \\
(85)\end{array}$ & 0.114 & 0.042 & 0.077 & 0.123 & 0.205 \\
\hline $\begin{array}{l}\text { Gini index of } \\
\text { income } \\
\text { distribution }\end{array}$ & $\begin{array}{c}0.403 \\
(67)\end{array}$ & 0.071 & 0.439 & 0.397 & 0.389 & 0.397 \\
\hline $\begin{array}{l}\text { Total population } \\
(000 \mathrm{~s})\end{array}$ & $\begin{array}{c}38,962 \\
(85)\end{array}$ & 47,889 & 26,836 & 33,118 & 40,333 & 49,369 \\
\hline $\begin{array}{l}\text { Real GDP per } \\
\text { capita - US } \\
\text { dollars (1985 } \\
\text { international } \\
\text { prices) }\end{array}$ & $\begin{array}{l}3,860.4 \\
(87)\end{array}$ & $3,513.2$ & 1,480 & 2,648 & 4,389 & 6,612 \\
\hline
\end{tabular}

Notes: Numbers in parentheses report the number of non-missing observations in each sample (or sub-sample). It includes 11 countries: Hong Kong, Indonesia, Japan, Korea, Malaysia, the Philippines, Singapore, Taiwan, Thailand, Fiji, and Papua New Guinea. 
Table A1d. Descriptive statistics — South Asia

\begin{tabular}{|c|c|c|c|c|c|c|}
\hline & $\begin{array}{l}\text { Mean } \\
\text { entire } \\
\text { sample }\end{array}$ & SD & $\begin{array}{c}\text { Mean } \\
\text { year }=60\end{array}$ & $\begin{array}{c}\text { Mean } \\
\text { year }=70\end{array}$ & $\begin{array}{c}\text { Mean } \\
\text { year }=80\end{array}$ & $\begin{array}{c}\text { Mean } \\
\text { year }=90\end{array}$ \\
\hline $\begin{array}{l}\text { Gross enrolment } \\
\text { rate in primary } \\
\text { education }\end{array}$ & $\begin{array}{c}0.699 \\
(40)\end{array}$ & 0.261 & 0.486 & 0.584 & 0.734 & 0.874 \\
\hline $\begin{array}{l}\text { Gross enrolment } \\
\text { rate in } \\
\text { secondary } \\
\text { education }\end{array}$ & $\begin{array}{c}0.277 \\
(40)\end{array}$ & 0.174 & 0.144 & 0.230 & 0.270 & 0.390 \\
\hline $\begin{array}{l}\text { Gross enrolment } \\
\text { rate in higher } \\
\text { education }\end{array}$ & $\begin{array}{c}0.036 \\
(40)\end{array}$ & 0.024 & 0.010 & 0.031 & 0.040 & 0.046 \\
\hline $\begin{array}{l}\text { Gini index of } \\
\text { income } \\
\text { distribution }\end{array}$ & $\begin{array}{c}0.352 \\
(32)\end{array}$ & 0.058 & 0.377 & 0.335 & 0.362 & 0.298 \\
\hline $\begin{array}{l}\text { Total population } \\
(000 \mathrm{~s})\end{array}$ & $\begin{array}{c}172,884 \\
(40)\end{array}$ & 263,567 & 112,602 & 142,258 & 178,410 & 221,599 \\
\hline $\begin{array}{l}\text { Real GDP per } \\
\text { capita - US } \\
\text { dollars (1985 } \\
\text { international } \\
\text { prices) }\end{array}$ & $\begin{array}{c}1,019.8 \\
(40)\end{array}$ & 382.6 & 792 & 914 & 1,123 & 1,446 \\
\hline
\end{tabular}

Notes: Numbers in parentheses report the number of non-missing observations in each sample (or sub-sample). It includes five countries: Bangladesh, India, Nepal, Pakistan, and Sri Lanka. 
Table A1e. Descriptive statistics — Latin America and the Caribbean

\begin{tabular}{|c|c|c|c|c|c|c|}
\hline & $\begin{array}{c}\text { Mean } \\
\text { entire } \\
\text { sample }\end{array}$ & SD & $\begin{array}{c}\text { Mean } \\
\text { year }=60\end{array}$ & $\begin{array}{c}\text { Mean } \\
\text { year }=70\end{array}$ & $\begin{array}{c}\text { Mean } \\
\text { year }=80\end{array}$ & $\begin{array}{c}\text { Mean } \\
\text { year }=90\end{array}$ \\
\hline $\begin{array}{l}\text { Gross enrolment } \\
\text { rate in primary } \\
\text { education }\end{array}$ & $\begin{array}{l}0.951 \\
(180)\end{array}$ & 0.117 & 0.872 & 0.932 & 0.965 & 0.970 \\
\hline $\begin{array}{l}\text { Gross enrolment } \\
\text { rate in } \\
\text { secondary } \\
\text { education }\end{array}$ & $\begin{array}{l}0.405 \\
(180)\end{array}$ & 0.203 & 0.195 & 0.323 & 0.475 & 0.521 \\
\hline $\begin{array}{l}\text { Gross enrolment } \\
\text { rate in higher } \\
\text { education }\end{array}$ & $\begin{array}{l}0.117 \\
(179)\end{array}$ & 0.092 & 0.029 & 0.064 & 0.138 & 0.186 \\
\hline $\begin{array}{l}\text { Gini index of } \\
\text { income } \\
\text { distribution }\end{array}$ & $\begin{array}{l}0.490 \\
(121)\end{array}$ & 0.077 & 0.489 & 0.504 & 0.493 & 0.493 \\
\hline $\begin{array}{l}\text { Total population } \\
\quad(000 \mathrm{~s})\end{array}$ & $\begin{array}{c}14,142 \\
(184)\end{array}$ & 26,831 & 8,848 & 11,658 & 14,889 & 18,114 \\
\hline $\begin{array}{l}\text { Real GDP per } \\
\text { capita - US } \\
\text { dollars (1985 } \\
\text { international } \\
\text { prices) }\end{array}$ & $\begin{array}{c}3,085.5 \\
(183)\end{array}$ & $1,737.9$ & 2,261 & 2,959 & 3,787 & 3,394 \\
\hline
\end{tabular}

Notes: Numbers in parentheses report the number of non-missing observations in each sample (or sub-sample). It includes 23 countries: Barbados, Costa Rica, Dominica, El Salvador, Guatemala, Honduras, Jamaica, Mexico, Nicaragua, Panama, Trinidad and Tobago, Argentina, Bolivia, Brazil, Chile, Colombia, Ecuador, Guyana, Paraguay, Peru, Surinam, Uruguay, and Venezuela. 
Table A1f. Descriptive statistics - OECD countries

\begin{tabular}{|c|c|c|c|c|c|c|}
\hline & $\begin{array}{l}\text { Mean } \\
\text { entire } \\
\text { sample }\end{array}$ & SD & $\begin{array}{c}\text { Mean } \\
\text { year }=60\end{array}$ & $\begin{array}{c}\text { Mean } \\
\text { year }=70\end{array}$ & $\begin{array}{c}\text { Mean } \\
\text { year }=80\end{array}$ & $\begin{array}{c}\text { Mean } \\
\text { year }=90\end{array}$ \\
\hline $\begin{array}{l}\text { Gross enrolment } \\
\text { rate in primary } \\
\text { education }\end{array}$ & $\begin{array}{l}0.992 \\
(176)\end{array}$ & 0.047 & 0.981 & 0.974 & 0.988 & 0.990 \\
\hline $\begin{array}{l}\text { Gross enrolment } \\
\text { rate in } \\
\text { secondary } \\
\text { education }\end{array}$ & $\begin{array}{l}0.773 \\
(174)\end{array}$ & 0.254 & 0.485 & 0.690 & 0.807 & 0.905 \\
\hline $\begin{array}{l}\text { Gross enrolment } \\
\text { rate in higher } \\
\text { education }\end{array}$ & $\begin{array}{l}0.253 \\
(175)\end{array}$ & 0.175 & 0.089 & 0.164 & 0.249 & 0.387 \\
\hline $\begin{array}{l}\text { Gini index of } \\
\text { income } \\
\text { distribution }\end{array}$ & $\begin{array}{l}0.358 \\
(131)\end{array}$ & 0.077 & 0.432 & 0.365 & 0.336 & 0.328 \\
\hline $\begin{array}{l}\text { Total population } \\
\quad(000 \mathrm{~s})\end{array}$ & $\begin{array}{c}29,227 \\
(179)\end{array}$ & 46,967 & 24,833 & 27,756 & 30,142 & 31,717 \\
\hline $\begin{array}{l}\text { Real GDP per } \\
\text { capita - US } \\
\text { dollars (1985 } \\
\text { international } \\
\text { prices) }\end{array}$ & $\begin{array}{c}9,674.5 \\
(179)\end{array}$ & $3,841.6$ & 5,842 & 8,355 & 10,544 & 12,666 \\
\hline
\end{tabular}

Notes: Numbers in parentheses report the number of non-missing observations in each sample (or sub-sample). It includes 23 countries: Australia, Austria, the Bahamas, Belgium, Canada, Denmark, Finland, France, (West) Germany, Greece, Ireland, Italy, Luxembourg, The Netherlands, New Zealand, Norway, Portugal, Spain, Sweden, Switzerland, Turkey, the UK, and the USA. 
Table A1g. Descriptive statistics — centrally planned economies

\begin{tabular}{|c|c|c|c|c|c|c|}
\hline & $\begin{array}{l}\text { Mean } \\
\text { entire } \\
\text { sample }\end{array}$ & SD & $\begin{array}{c}\text { Mean } \\
\text { year }=60\end{array}$ & $\begin{array}{c}\text { Mean } \\
\text { year }=70\end{array}$ & $\begin{array}{c}\text { Mean } \\
\text { year = 80 }\end{array}$ & $\begin{array}{c}\text { Mean } \\
\text { year }=90\end{array}$ \\
\hline $\begin{array}{l}\text { Gross enrolment } \\
\text { rate in primary } \\
\text { education }\end{array}$ & $\begin{array}{c}0.978 \\
(34)\end{array}$ & 0.082 & 1.000 & 0.965 & 0.987 & 0.912 \\
\hline $\begin{array}{l}\text { Gross enrolment } \\
\text { rate in } \\
\text { secondary } \\
\text { education }\end{array}$ & $\begin{array}{c}0.646 \\
(33)\end{array}$ & 0.189 & 0.365 & 0.530 & 0.692 & 0.680 \\
\hline $\begin{array}{l}\text { Gross enrolment } \\
\text { rate in higher } \\
\text { education }\end{array}$ & $\begin{array}{c}0.168 \\
(27)\end{array}$ & 0.091 & 0.078 & 0.133 & 0.174 & 0.142 \\
\hline $\begin{array}{l}\text { Gini index of } \\
\text { income } \\
\text { distribution }\end{array}$ & $\begin{array}{c}0.274 \\
(44)\end{array}$ & 0.056 & 0.242 & 0.245 & 0.270 & 0.273 \\
\hline $\begin{array}{l}\text { Total population } \\
(000 \mathrm{~s})\end{array}$ & $\begin{array}{l}269,046 \\
(31)\end{array}$ & 415,109 & 337,947 & 425,523 & 509,219 & 196,341 \\
\hline $\begin{array}{l}\text { Real GDP per } \\
\text { capita - US } \\
\text { dollars (1985 } \\
\text { international } \\
\text { prices) }\end{array}$ & $\begin{array}{l}3,538.1 \\
(34)\end{array}$ & $1,298.5$ & 1,953 & 2,629 & 4,099 & 4,058 \\
\hline
\end{tabular}

Notes: Numbers in parentheses report the number of non-missing observations in each sample (or sub-sample). It includes seven countries: China, Hungary, Poland, Yugoslavia, Bulgaria, Romania, and (former) Soviet Union. 
Table A2. Descriptive statistics, 1960-95

\begin{tabular}{|c|c|c|c|c|c|}
\hline Variable & Obs & Mean & SD & Min & Max \\
\hline $\begin{array}{l}\text { Gross enrolment rate in primary } \\
\text { education }\end{array}$ & 470 & 0.900 & 0.190 & 0.050 & 1.350 \\
\hline $\begin{array}{l}\text { Gross enrolment rate in secondary } \\
\text { education }\end{array}$ & 470 & 0.482 & 0.291 & 0.005 & 1.065 \\
\hline $\begin{array}{l}\text { Gross enrolment rate in higher } \\
\text { education }\end{array}$ & 470 & 0.134 & 0.135 & 0.000 & 0.947 \\
\hline Gini index of income distribution & 470 & 0.422 & 0.101 & 0.233 & 0.795 \\
\hline $\begin{array}{l}\text { Income share of the lowest quintile } \\
\text { in income distribution }\end{array}$ & 319 & 0.059 & 0.020 & 0.016 & 0.109 \\
\hline $\begin{array}{l}\text { Fertility rate (potential children per } \\
\text { woman) }\end{array}$ & 460 & 4.351 & 1.944 & 1.440 & 8.256 \\
\hline $\begin{array}{l}\text { Crude birth rate (per } 1,000 \\
\text { inhabitants) }\end{array}$ & 462 & 29.508 & 12.716 & 9.000 & 57.200 \\
\hline $\begin{array}{l}\text { Children mortality rate in the first } \\
\text { year (per } 1,000 \text { births) }\end{array}$ & 466 & 0.060 & 0.049 & 0.001 & 0.218 \\
\hline $\begin{array}{l}\text { Government current expenditure in } \\
\text { primary education per pupil - US } \\
\text { dollars (PPP-adjusted } 1985 \\
\text { international prices) }\end{array}$ & 358 & 764.1 & $1,042.9$ & 25.0 & $7,003.0$ \\
\hline $\begin{array}{l}\text { Government current expenditure in } \\
\text { secondary education per pupil - } \\
\text { US dollars (PPP-adjusted } 1985 \\
\text { international prices) }\end{array}$ & 338 & $1,027.5$ & 951.2 & 32.0 & $4,572.0$ \\
\hline $\begin{array}{l}\text { Students per teacher in primary } \\
\text { education }\end{array}$ & 469 & 31.3 & 11.8 & 6.1 & 90.4 \\
\hline $\begin{array}{l}\text { Students per teacher in secondary } \\
\text { education }\end{array}$ & 447 & 19.5 & 6.7 & 6.1 & 44.2 \\
\hline $\begin{array}{l}\text { Students per teacher in higher } \\
\text { education }\end{array}$ & 193 & 15.7 & 10.6 & 4.3 & 127.8 \\
\hline $\begin{array}{l}\text { Real GDP per capita - US dollars } \\
\text { (PPP-adjusted } 1985 \text { international } \\
\text { prices) }\end{array}$ & 470 & $4,524.9$ & $4,061.0$ & 308.0 & $18,399.0$ \\
\hline $\begin{array}{l}\text { Ratio of physical capital stock to } \\
\text { GDP (1987 local prices) }\end{array}$ & 413 & 2.598 & 0.965 & 0.674 & 7.432 \\
\hline $\begin{array}{l}\text { Share of the population over } 15 \text { with } \\
\text { some primary education }\end{array}$ & 430 & 43.49 & 17.85 & 2.2 & 90.1 \\
\hline $\begin{array}{l}\text { Average years of completed primary } \\
\text { education in the population over } 15\end{array}$ & 428 & 3.941 & 1.758 & 0.2 & 8.1 \\
\hline $\begin{array}{l}\text { Average years of completed secondary } \\
\text { education in the population over } 15\end{array}$ & 430 & 1.331 & 0.987 & 0.0 & 5.1 \\
\hline
\end{tabular}


Table A3. Panel probit regression on the availability of income distribution data - GEE population averaged model regression — robust estimates, 1960-95

\begin{tabular}{lccc}
\hline $\begin{array}{l}\text { Dependent variable: (1: income data } \\
\text { available; 0: income data not available) }\end{array}$ & $\begin{array}{c}\text { Estimated } \\
\text { coefficients }\end{array}$ & $\begin{array}{c}\text { Semi-robust } \\
\text { SE }\end{array}$ & p-values \\
\hline (Log of) real GDP per capita & 0.013 & 0.030 & 0.672 \\
(Log of) population & 0.242 & 0.077 & 0.002 \\
Growth rate of population & -0.168 & 0.138 & 0.223 \\
Gross enrolment rate in primary & -0.036 & 0.064 & 0.570 \\
$\quad$ education & & & \\
Gross enrolment rate in secondary & 0.034 & 0.044 & 0.431 \\
$\quad$ education & & & \\
Gross enrolment rate in higher & 0.218 & 0.091 & 0.017 \\
$\quad$ education & & & \\
Dummy for OECD countries & 0.600 & 0.553 & 0.278 \\
Dummy for North African and & -1.044 & 0.487 & 0.032 \\
$\quad$ Middle East countries & & & \\
Dummy for sub-Saharan countries & -0.502 & 0.468 & 0.283 \\
Dummy for Latin American countries & 0.661 & 0.655 & 0.313 \\
Dummy for year $=1965$ & -0.029 & 0.010 & 0.007 \\
Dummy for year $=1970$ & -0.055 & 0.020 & 0.006 \\
Dummy for year $=1975$ & -0.085 & 0.030 & 0.005 \\
Dummy for year $=1980$ & -0.120 & 0.040 & 0.003 \\
Dummy for year $=1985$ & -0.157 & 0.049 & 0.001 \\
Dummy for year $=1990$ & -0.190 & 0.058 & 0.001 \\
Dummy for year $=1995$ & -0.209 & 0.068 & 0.002 \\
Constant & -0.880 & 0.861 & 0.307 \\
No. of observations/No. of countries & & $891 / 132$ & \\
$\quad \chi^{2}$ test & & $94.67(0.00)$ & \\
\hline & & & \\
\hline
\end{tabular}

(c) CEIS, Fondazione Giacomo Brodolini and Blackwell Publishers Ltd 2003. 
Table A4. Estimation of primary enrolment — random-effects tobit regressions, 1960-95

\begin{tabular}{lcccc}
\hline & \multicolumn{4}{c}{ Estimated coefficients } \\
\cline { 2 - 5 } $\begin{array}{l}\text { Dependent variable: gross enrolment } \\
\text { rate in primary education }\end{array}$ & Total & Total & Total & Female \\
\hline Gini index of income distribution & 0.15 & -0.21 & - & -0.05 \\
& $(0.11)$ & $(0.23)$ & & $(0.13)$ \\
Income share of the lowest quintile & - & -0.58 & - & - \\
$\quad$ in income distribution & & $(0.82)$ & & 0.08 \\
(Log of) real GDP per capita & 0.06 & 0.06 & - & $(0.02)$ \\
& $(0.02)$ & $(0.02)$ & & - \\
(Log of) inequality-adjusted real & - & - & 0.04 & $-0.02)$ \\
$\quad$ GNP per capita & & & -2.32 & -2.88 \\
Children mortality rate in the first & -2.27 & -1.72 & $(0.43)$ & $(0.47)$ \\
$\quad$ year (per 1,000 births) & $(0.42)$ & $(0.36)$ & 0.06 & 0.07 \\
Fertility rate (potential children per & 0.06 & 0.06 & 0.06 \\
$\quad$ woman) & $(0.01)$ & $(0.02)$ & $(0.01)$ & $(0.02)$ \\
Crude birth rate (per 1,000 & -0.01 & -0.01 & -0.01 & -0.01 \\
$\quad$ inhabitants) & $(0.002)$ & $(0.002)$ & $(0.002)$ & $(0.002)$ \\
Share of the corresponding & 0.20 & 0.15 & 0.20 & 0.27 \\
$\quad$ population over 15 with some & $(0.06)$ & $(0.06)$ & $(0.06)$ & $(0.07)$ \\
$\quad$ primary education & & & & \\
Students per teacher in primary & 0.002 & 0.003 & 0.002 & 0.002 \\
$\quad$ education & $(0.001)$ & $(0.001)$ & $(0.001)$ & $(0.001)$ \\
Average salary primary school & - & - & - & - \\
$\quad$ teacher/GDP per capita & & & & \\
Constant & Yes & Yes & Yes & Yes \\
Regional dummies & Yes & Yes & Yes & Yes \\
No. of observations/No. of countries & $436 / 92$ & $303 / 84$ & $436 / 92$ & $433 / 92$ \\
Wald $\chi^{2}$ test & 381.4 & 305.1 & 328.6 & 415.5 \\
$\quad$ & $(0.00)$ & $(0.00)$ & $(0.00)$ & $(0.00)$ \\
Log-likelihood & 23.33 & 34.65 & 21.11 & 9.28 \\
\hline & & & & \\
\hline
\end{tabular}

Note: Standard errors in parentheses. 
Table A5. Estimation of secondary enrolment — random-effects GLS robust regressions, 1960-95

\begin{tabular}{lcccc}
\hline & \multicolumn{4}{c}{ Estimated coefficients } \\
\cline { 2 - 5 } $\begin{array}{l}\text { Dependent variable: gross enrolment } \\
\text { rate in primary education }\end{array}$ & Total & Total & Total & Female \\
\hline Gini index of income distribution & -0.27 & -0.18 & - & -0.34 \\
& $(0.10)$ & $(0.27)$ & & $(0.11)$ \\
& - & 0.15 & - & - \\
Income share of the lowest quintile & - & $(0.98)$ & & 0.12 \\
$\quad$ in income distribution & 0.12 & 0.11 & - & $(0.03)$ \\
(Log of) real GDP per capita & $(0.02)$ & $(0.02)$ & & - \\
& - & - & $(0.12$ & \\
(Log of) inequality-adjusted real & & & $-0.02)$ & -0.05 \\
$\quad$ GNP per capita & -0.04 & -0.05 & -0.04 & $(0.01)$ \\
Fertility rate (potential children & $(0.01)$ & $(0.01)$ & $(0.01)$ & 0.04 \\
$\quad$ per woman) & 0.05 & 0.03 & 0.05 & 0.01 \\
Average years of completed & $(0.01)$ & $(0.01)$ & $(0.01)$ & $(0.01)$ \\
$\quad$ primary education in the & & & & \\
$\quad$ corresponding population over 15 & 0.04 & 0.06 & 0.04 & 0.05 \\
Ratio of physical capital stock to & $(0.01)$ & $(0.02)$ & $(0.01)$ & $(0.01)$ \\
$\quad$ GDP (1987 local prices) & Yes & Yes & Yes & Yes \\
Constant & Yes & Yes & Yes & Yes \\
Regional dummies & $386 / 76$ & $264 / 69$ & $386 / 76$ & $369 / 76$ \\
No. of observations/No. of countries & 876.5 & 730.6 & 844.5 & 882.3 \\
$\quad \chi^{2}$ test & $(0.00)$ & $(0.00)$ & $(0.00)$ & $(0.00)$ \\
\hline
\end{tabular}

Note: Standard errors in parentheses. 
Table A6. Estimation of higher education enrolment — random-effects GLS robust regressions, 1960-95

\begin{tabular}{|c|c|c|c|c|c|}
\hline \multirow{2}{*}{$\begin{array}{l}\text { Dependent variable: gross } \\
\text { enrolment rate in primary } \\
\text { education }\end{array}$} & \multicolumn{5}{|c|}{ Estimated coefficients } \\
\hline & Total & Total & Total & Female & Male \\
\hline $\begin{array}{l}\text { Gini index of income } \\
\text { distribution }\end{array}$ & $\begin{array}{l}-0.08 \\
(0.06)\end{array}$ & $\begin{array}{c}0.05 \\
(0.21)\end{array}$ & - & $\begin{array}{l}-0.08 \\
(0.05)\end{array}$ & $\begin{array}{l}-0.14 \\
(0.05)\end{array}$ \\
\hline $\begin{array}{l}\text { Income share of the lowest } \\
\text { quintile in income } \\
\text { distribution }\end{array}$ & - & $\begin{array}{c}0.22 \\
(0.65)\end{array}$ & - & - & - \\
\hline $\begin{array}{l}\text { (Log of) real GDP per } \\
\text { capita }\end{array}$ & $\begin{array}{r}0.05 \\
(0.02)\end{array}$ & $\begin{array}{c}0.07 \\
(0.03)\end{array}$ & - & $\begin{array}{r}0.03 \\
(0.02)\end{array}$ & $\begin{array}{r}0.05 \\
(0.02)\end{array}$ \\
\hline $\begin{array}{l}\text { (Log of) inequality-adjusted } \\
\text { real GNP per capita }\end{array}$ & - & - & $\begin{array}{c}0.05 \\
(0.02)\end{array}$ & - & - \\
\hline $\begin{array}{l}\text { (Log of) government current } \\
\text { expenditure in secondary } \\
\text { education per pupil (PPP- } \\
\text { adjusted } 1985 \text { international } \\
\text { prices) }\end{array}$ & $\begin{array}{r}0.01 \\
(0.01)\end{array}$ & $\begin{array}{c}0.01 \\
(0.01)\end{array}$ & $\begin{array}{c}0.01 \\
(0.01)\end{array}$ & $\begin{array}{r}0.01 \\
(0.01)\end{array}$ & $\begin{array}{l}0.004 \\
(0.01)\end{array}$ \\
\hline $\begin{array}{l}\text { Average years of completed } \\
\text { secondary education in the } \\
\text { corresponding population } \\
\text { over } 15\end{array}$ & $\begin{array}{r}0.07 \\
(0.01)\end{array}$ & $\begin{array}{c}0.06 \\
(0.01)\end{array}$ & $\begin{array}{c}0.07 \\
(0.01)\end{array}$ & $\begin{array}{r}0.07 \\
(0.01)\end{array}$ & $\begin{array}{r}0.05 \\
(0.00)\end{array}$ \\
\hline $\begin{array}{l}\text { Ratio of physical capital stock } \\
\text { to GDP (1987 local prices) }\end{array}$ & $\begin{array}{c}0.01 \\
(0.00)\end{array}$ & $\begin{array}{c}0.01 \\
(0.01)\end{array}$ & $\begin{array}{c}0.01 \\
(0.00)\end{array}$ & $\begin{array}{r}0.01 \\
(0.00)\end{array}$ & $\begin{array}{c}0.01 \\
(0.00)\end{array}$ \\
\hline Constant & Yes & Yes & Yes & Yes & Yes \\
\hline Regional dummies & Yes & Yes & Yes & Yes & Yes \\
\hline $\begin{array}{l}\text { No. of observations/No. of } \\
\text { countries } \chi^{2} \text { test }\end{array}$ & $\begin{array}{l}303 / 72 \\
270.3 \\
(0.00)\end{array}$ & $\begin{array}{l}210 / 65 \\
178.6 \\
(0.00)\end{array}$ & $\begin{array}{l}303 / 72 \\
264.7 \\
(0.00)\end{array}$ & $\begin{array}{l}254 / 70 \\
194.7 \\
(0.00)\end{array}$ & $\begin{array}{l}253 / 69 \\
398.2 \\
(0.00)\end{array}$ \\
\hline
\end{tabular}

Note: Standard errors in parentheses. 
Table A7. Cross-section OLS and tobit regressions, 1960-95. Estimated coefficients on Gini index

\begin{tabular}{|c|c|c|c|c|c|c|c|c|}
\hline \multirow[b]{2}{*}{ Year } & \multicolumn{4}{|c|}{ Total enrolment } & \multicolumn{4}{|c|}{ Female enrolment } \\
\hline & Primary & $\begin{array}{c}\text { Primary } \\
\text { tobit }\end{array}$ & Secondary & Higher & Primary & $\begin{array}{c}\text { Primary } \\
\text { tobit }\end{array}$ & Secondary & Higher \\
\hline 1960 & $\begin{array}{l}0.049 \\
(0.17)\end{array}$ & $\begin{array}{c}-0.021 \\
(0.06)\end{array}$ & $\begin{array}{c}-0.257 \\
(1.12)\end{array}$ & $\begin{array}{c}-0.123 \\
(1.26)\end{array}$ & $\begin{array}{c}0.008 \\
(0.023)\end{array}$ & $\begin{array}{c}-0.142 \\
(0.28)\end{array}$ & $\begin{array}{c}-0.217 \\
(0.90)\end{array}$ & $\begin{array}{c}-0.045 \\
(0.69)\end{array}$ \\
\hline 1965 & $\begin{array}{l}0.232 \\
(1.20)\end{array}$ & $\begin{array}{c}0.502 \\
(1.88)\end{array}$ & $\begin{array}{l}0.067 \\
(0.34)\end{array}$ & $\begin{array}{c}-0.050 \\
(0.56)\end{array}$ & $\begin{array}{c}0.231 \\
(1.12)\end{array}$ & $\begin{array}{l}0.385 \\
(1.32)\end{array}$ & $\begin{array}{c}-0.038 \\
(0.18)\end{array}$ & $\begin{array}{c}-0.016 \\
(0.19)\end{array}$ \\
\hline 1970 & $\begin{array}{l}0.552 \\
(2.95)\end{array}$ & $\begin{array}{l}0.546 \\
(2.00)\end{array}$ & $\begin{array}{c}-0.376 \\
(2.18)\end{array}$ & $\begin{array}{c}-0.111 \\
(1.21)\end{array}$ & $\begin{array}{l}0.637 \\
(3.53)\end{array}$ & $\begin{array}{l}0.676 \\
(2.94)\end{array}$ & $\begin{array}{c}-0.242 \\
(1.31)\end{array}$ & $\begin{array}{c}-0.043 \\
(0.52)\end{array}$ \\
\hline 1975 & $\begin{array}{c}0.047 \\
(0.224)\end{array}$ & $\begin{array}{l}0.238 \\
(0.65)\end{array}$ & $\begin{array}{l}-0.562 \\
(2.03)\end{array}$ & $\begin{array}{c}-0.136 \\
(0.83)\end{array}$ & $\begin{array}{l}0.270 \\
(1.06)\end{array}$ & $\begin{array}{l}0.574 \\
(1.61)\end{array}$ & $\begin{array}{c}-0.255 \\
(0.86)\end{array}$ & $\begin{array}{c}-0.034 \\
(0.21)\end{array}$ \\
\hline 1980 & $\begin{array}{l}0.425 \\
(2.63)\end{array}$ & $\begin{array}{l}1.032 \\
(3.03)\end{array}$ & $\begin{array}{l}-0.545 \\
(2.33)\end{array}$ & $\begin{array}{c}-0.271 \\
(1.71)\end{array}$ & $\begin{array}{l}0.545 \\
(2.75)\end{array}$ & $\begin{array}{l}1.00 \\
(2.57)\end{array}$ & $\begin{array}{c}-0.256 \\
(1.01)\end{array}$ & $\begin{array}{r}-0.227 \\
(1.30)\end{array}$ \\
\hline 1985 & $\begin{array}{l}0.398 \\
(2.43)\end{array}$ & $\begin{array}{l}0.715 \\
(1.97)\end{array}$ & $\begin{array}{c}-0.634 \\
(2.79)\end{array}$ & $\begin{array}{l}0.115 \\
(0.54)\end{array}$ & $\begin{array}{l}0.582 \\
(3.06)\end{array}$ & $\begin{array}{l}1.11 \\
(2.94)\end{array}$ & $\begin{array}{c}-0.395 \\
(1.93)\end{array}$ & $\begin{array}{l}0.082 \\
(0.36)\end{array}$ \\
\hline 1990 & $\begin{array}{l}0.214 \\
(1.58)\end{array}$ & $\begin{array}{l}0.412 \\
(1.70)\end{array}$ & $\begin{array}{c}-0.468 \\
(2.58)\end{array}$ & $\begin{array}{c}-0.059 \\
(0.31)\end{array}$ & $\begin{array}{l}0.368 \\
(2.27)\end{array}$ & $\begin{array}{l}0.458 \\
(1.78)\end{array}$ & $\begin{array}{c}-0.219 \\
(1.16)\end{array}$ & n.a. \\
\hline 1995 & $\begin{array}{l}0.496 \\
(1.71)\end{array}$ & $\begin{array}{l}0.060 \\
(0.18)\end{array}$ & $\begin{array}{c}-0.452 \\
(1.62)\end{array}$ & n.a. & $\begin{array}{l}0.644 \\
(1.54)\end{array}$ & $\begin{array}{l}0.286 \\
(0.59)\end{array}$ & $\begin{array}{c}-0.014 \\
(0.06)\end{array}$ & n.a. \\
\hline
\end{tabular}

Notes: $t$-statistics in parentheses. The specification for primary enrolment corresponds to the first column of Table 2 and includes as regressors: log of real GDP per capita, child mortality, fertility rate, crude birth rate, share of the population over 15 with some primary education, and students per teacher. The specification for secondary enrolment corresponds to the first column of Table 4 and includes as regressors: $\log$ of real GDP per capita, fertility rate, average year of completed primary education in the population over 15, and ratio of capital stock to output. The specification for higher enrolment corresponds to the first column of Table 6 and includes as regressors: log of real GDP per capita, average year of completed secondary education in the population over 15 , expenditure per pupil in secondary education over GDP per capita, and ratio of capital stock to output. 
Table A8. Regional effects on enrolment — random-effects GLS regressions, 1960-95. Estimated coefficients on Gini index

\begin{tabular}{|c|c|c|c|c|c|c|}
\hline & \multicolumn{3}{|c|}{ Total enrolment } & \multicolumn{3}{|c|}{ Female enrolment } \\
\hline & Primary & Secondary & Higher & Primary & Secondary & Higher \\
\hline $\begin{array}{l}\text { Sub-Saharan } \\
\text { Africa }\end{array}$ & $\begin{array}{l}0.464 \\
(0.24)\end{array}$ & $\begin{array}{l}0.024 \\
(0.19)\end{array}$ & $\begin{array}{l}-0.007 \\
(0.02)\end{array}$ & $\begin{array}{l}0.332 \\
(0.24)\end{array}$ & $\begin{array}{l}0.058 \\
(0.18)\end{array}$ & $\begin{array}{c}-0.004 \\
(0.00)\end{array}$ \\
\hline $\begin{array}{l}\text { North Africa and } \\
\text { Middle East }\end{array}$ & $\begin{array}{l}1.235 \\
(0.40)\end{array}$ & $\begin{array}{l}-2.46 \\
(0.63)\end{array}$ & $\begin{array}{l}0.565 \\
(0.33)\end{array}$ & $\begin{array}{l}1.759 \\
(0.46)\end{array}$ & $\begin{array}{c}-2.178 \\
(0.63)\end{array}$ & $\begin{array}{l}0.433 \\
(0.15)\end{array}$ \\
\hline $\begin{array}{l}\text { East Asia and the } \\
\text { Pacific }\end{array}$ & $\begin{array}{c}-0.002 \\
(0.21)\end{array}$ & $\begin{array}{l}0.048 \\
(0.30)\end{array}$ & $\begin{array}{l}0.063 \\
(0.19)\end{array}$ & $\begin{array}{l}-0.522 \\
(0.27)\end{array}$ & $\begin{array}{l}0.243 \\
(0.34)\end{array}$ & $\begin{array}{c}-0.019 \\
(0.15)\end{array}$ \\
\hline South Asia & $\begin{array}{l}0.113 \\
(0.37)\end{array}$ & $\begin{array}{l}-0.324 \\
(0.25)\end{array}$ & $\begin{array}{l}-0.095 \\
(0.10)\end{array}$ & $\begin{array}{l}0.208 \\
(0.35)\end{array}$ & $\begin{array}{l}-0.355 \\
(0.30)\end{array}$ & $\begin{array}{l}0.021 \\
(0.10)\end{array}$ \\
\hline $\begin{array}{l}\text { Latin America and } \\
\text { the Caribbean }\end{array}$ & $\begin{array}{l}-0.010 \\
(0.09)\end{array}$ & $\begin{array}{c}-0.029 \\
(0.13)\end{array}$ & $\begin{array}{c}-0.036 \\
(0.08)\end{array}$ & $\begin{array}{c}-0.109 \\
(0.09)\end{array}$ & $\begin{array}{c}-0.045 \\
(0.13)\end{array}$ & $\begin{array}{c}-0.085 \\
(0.08)\end{array}$ \\
\hline OECD countries & $\begin{array}{l}0.104 \\
(0.05)\end{array}$ & $\begin{array}{l}-0.067 \\
(0.16)\end{array}$ & $\begin{array}{l}0.070 \\
(0.13)\end{array}$ & $\begin{array}{c}-0.070 \\
(0.09)\end{array}$ & $\begin{array}{c}-0.349 \\
(0.17)\end{array}$ & $\begin{array}{l}0.121 \\
(0.10)\end{array}$ \\
\hline $\begin{array}{l}\text { Centrally planned } \\
\text { economies }\end{array}$ & $\begin{array}{l}0.769 \\
(0.43)\end{array}$ & n.a. & n.a. & $\begin{array}{l}0.860 \\
(0.61)\end{array}$ & n.a. & n.a. \\
\hline
\end{tabular}

Notes: Standard errors in parentheses. The specification for primary enrolment corresponds to the first column of Table 2 and includes as regressors: log of real GDP per capita, child mortality, fertility rate, crude birth rate, share of the population over 15 with some primary education, and students per teacher. The specification for secondary enrolment corresponds to the first column of Table 4 and includes as regressors: log of real GDP per capita, fertility rate, average year of completed primary education in the population over 15 , and ratio of capital stock to output. The specification for higher enrolment corresponds to the first column of Table 6 and includes as regressors: log of real GDP per capita, average year of completed secondary education in the population over 15 , expenditure per pupil in secondary education over GDP per capita, and ratio of capital stock to output. 


\section{Notes}

${ }^{1}$ A good survey of the recent literature is contained in Benabou (1996c).
${ }^{2}$ See Alesina and Rodrik (1994), Persson and Tabellini (1994), Perotti (1993),
Bertola (1993).
${ }^{3}$ See Alesina and Perotti (1996). An additional variant is provided in Mauro (1995), where inequality fosters corruption and depresses investment.

${ }^{4}$ See Galor and Zeira (1993), Banerjee and Newman (1993), Torvik (1993), Benabou (1996a, b).

${ }^{5}$ Piketty (1997) claims that it is impossible to create financial markets to finance education, since (future) work effort is unobservable and contracts contingent on it are not enforceable.

${ }^{6}$ Redistributing incomes among agents is not the only way to increase efficiency. A scheme of education subsidies financed through taxation of future incomes (intertemporal redistribution) re-creates the missing market, and allows the attainment of a situation of Pareto optimality. See Banerjee and Newman (1993).

${ }^{7}$ Benabou (1996c) states that one standard deviation reduction in inequality increase GNP per capita of about 0.5-0.7 per cent. Perotti (1996) found that a GNP 1 per cent increase in middle incomes (proxied by third and fourth quartiles in income distribution) yields an increase in GNP per capita growth rate of the order of 0.2 per cent. Persson and Tabellini (1994) provide a higher estimate (of the order of 0.7 per cent).

${ }^{8}$ Barro (2000) found a negative correlation for poor countries (i.e. GDP per capita below US\$2070 (1985 dollars)) but a positive one for rich countries. Forbes (2000) discusses alternative reasons (measurement errors, omitted variable bias) why negative correlation could represent a distorted outcome; using panel techniques she found a positive correlation of past inequality on current growth rates within each country.

${ }^{9}$ Which is actually positive and significant, as found in Perotti (1996). The same author, when discussing Benabou (1996c), suggests a reverse causation: fastgrowing economies have more resources available for redistribution. Alesina (1998) points out that most of the redistributive policies in developing countries benefit the middle class rather than the poorest.

${ }^{10}$ The relationship between inequality and political instability can be read in a reverse way: harsh social conflict (e.g. during coups) may cause high casualties but, if successful, introduces regressive policies that increase income inequality (e.g. the Chilean case).

${ }^{11}$ Bourguignon (1994) found an overall negative relationship between inequality and growth in a sample of 35 small-medium-sized developing countries. His results are driven mainly by the sub-sample of Asian countries, which experienced early land redistribution and more compressed income distribution, combined with government efforts to encourage higher education. He also points out that a positive relationship between inequality and growth could apply to Latin American countries, via financing of investment (more inequality implies greater profits and therefore more financing opportunities for investment). Brandolini and Rossi (1998) made an effort to strengthen data comparability in a sample of 17 countries, and did not find a persistent relationship between household income inequality and growth (even if they speak of social institutions, where the link could be either positive or negative depending on the country area). 
${ }^{12}$ This proposition is not tested in the present paper, but finds support in the literature. Cf. Barro (1991, 1997).

${ }^{13}$ Or any possible combination of the two cases. If, for example, expected future income is a positive function of talent, randomly distributed in each generation, poor individuals are the less talented children of both rich and poor families. See Chiu (1998).

${ }^{14}$ See Ichino and Winter-Ebmer (1999) regarding the problems arising when trying to discriminate between the two explanations.

${ }^{15}$ For example, by looking at the significance of $\alpha_{1}$, which derives from the inversion of equation [5], one can infer the potential existence of ability transmission. A similar strategy is used by Becker and Tomes (1986), where they replace $S_{t-1}$ with $X_{t-1}$, grandparents' income.

${ }^{16}$ See, for example, Cowell (1995, p. 141).

${ }^{17}$ Whenever $\left(\log \left(n_{i}\right)-\gamma_{0}\right) / \gamma_{1}<\left(\sigma_{x}^{2} / \sqrt{2}\right)+\mu_{x}$ one has to consider the opposite of an integral with inverted extremes of integration.

${ }^{18}$ It is known that the Gini concentration index corresponds to the ratio of the areas in the Lorenz graph: $G_{X}=A /(A+B)$.

${ }^{19}$ There are alternative cases where we have variations in the distribution of $s$ independently of changes in income dispersion (as measured by the Gini concentration index): an increase in mean income for a given variance yields an increase in the access to education for any level of income; alternatively, if we modify the relationship between income and education (due to a change in the shift parameter $\gamma_{0}$ that reflects educational expenditure, technology, returns to schooling and stage of development), once again we obtain an increase in educational achievements for any given level of income.

${ }^{20}$ Barro and Lee (1994) is in turn based on Summers and Heston (1991). The original data by Barro and Lee (1996) have been criticized on methodological grounds, as they mix different sources and definitions (de la Fuente, Doménech, 2001). The authors have recognized some of these criticisms (Barro, Lee, 2001).

${ }^{21}$ Atkinson and Brandolini (2001) criticize the mixing of different secondary sources on the grounds of the impossibility of making meaningful comparisons across countries. However, provided we control for country fixed effects, this problem is attenuated.

${ }^{22}$ See, for example, Grilli (1994), Jones (1997) or Li et al. (1998).

${ }^{23}$ Deininger and Squire (1996) provide data of different quality, according to the coverage of the sample, the inclusion/exclusion of non-labour incomes and information about the recipients (individuals or families). Using what they define as 'high-quality' data reduces the available observations to 277 (which do not include data referred to 1995). However, the results are not very different when extended to include the 'low quality' data even if, given their greater variability, the estimates are less efficient. They also stress the different source of information (incomes or expenditure), but controlling with a dummy on this aspect (either unconstrained or interacted with the Gini variable) does not lead to statistically significant results for the control dummy, implying that different information sources do not affect the intercept of the relationship. Estimates on a restricted sample including only 'high-quality' data are available from the author. The original Deininger and Squire (1996) data set has been expanded using additional observations for 1995 from the World Bank (1998).

${ }^{24}$ Information on the private provision of schooling is scattered, and therefore we cannot take into account information on the supply of private schooling. 
Arnove et al. (1997) report an impressive increase in private institutions providing education, especially at university level, as a consequence of the decline in public expenditure in education: in Latin America the share of students enrolled in private universities rose from 5 per cent in 1970 to approximately 30 per cent in 1990 .

${ }^{25}$ In addition, remember that our model described by equation [7] predicts that the distribution of educational attainments in one generation depends, among others, on the same distribution for the previous generation.

${ }^{26}$ The insignificance of the estimated coefficient for the Gini index is robust against model misspecification (using the Huber-White estimator) and censoring of the dependent variable (random-effects tobit model estimation). Both estimates are available on request.

${ }^{27}$ Random-effects estimations for censored data do not imply significant differences (available from the author).

${ }^{28}$ Both estimates are available from the author.

${ }^{29}$ And social structures, at least for the case of castes in India. In this country primary education is not compulsory, and child labour is legal. The huge variation in literacy rates (which is 74 per cent among urban males and 20 per cent among rural females) is supposedly explained by the following factors:

The central proposition of this study is that India's low per capita income and economic situation is less relevant as an explanation than the belief systems of the state bureaucracy ... At the core of these beliefs are the Indian view of the social order, notions concerning the respective roles of upper and lower social strata, the role of education as a means of maintaining differentiations among social classes, and concerns that 'excessive' and 'inappropriate' education for the poor would disrupt existing social arrangements. (Weiner, 1991, p. 5)

${ }^{30}$ Unfortunately, child mortality proxies too many effects that interplay with primary education. For example, child mortality is negatively correlated with mothers' education and with health conditions (sanitation, doctors' availability, etc.). For this reason we do not want to put excessive emphasis on an 'income distribution' interpretation. However, using household surveys, Filmer and Pritchett (1998) show that the first principal component extracted from information on ownership of durable goods and quality of housing is a rather good predictor of educational attainment.

${ }^{31}$ See the various issues of the Human Development Report (UNDP, 1997).

${ }^{32}$ In the case of Tanzania, for example, where primary attendance was 0.34 in 1970, 0.93 in 1980 and 0.70 in 1990, class dimension can vary between 30 and 74 in rural areas. See Tibaijuka and Cormack (1998).

${ }^{33}$ That the number of students per teacher does not represent a good proxy for school quality has already been pointed out (see, for example, Hanushek, 1986, 1995, 1996).

${ }^{34}$ The fertility rate indicates the number of potential children that an 'average' woman - i.e. following the average behaviour of the country in terms of marriage age, frequency of pregnancies, etc. - could give birth to during her period of fertility. We also found a variable describing the 'number of person per family' (source: World Bank - correlation coefficient with fertility rate $=0.73$ ), but it has too few observations (211 for the whole sample) and therefore we had to discard it.

${ }^{35}$ Similar results were obtained by Schultz (1988) on a sample of 155 countries over the period 1950-80, where he found a positive effect of the relative size of school-aged population on enrolment rates for primary education. 
${ }^{36}$ Introducing the illiteracy rate as an explanatory variable proves statistically significant, with a negative sign, but the number of observations drops to 195 (corresponding to 69 countries). Contrariwise, when using the number of daily newspapers or the number of radio sets per 1,000 inhabitants, one obtains negative but statistically insignificant coefficients.

${ }^{37}$ Working on household surveys collected in 35 countries, Filmer and Pritchett (1998) have shown that:

Very low primary attainment by the poor is driven by two distinct patterns of enrolment and drop-out. There is a South-Asian and Western/Central African pattern in which many of the poor never enrol in school. In these countries more than 40 per cent of poor children never complete even grade 1 and typically only one in four complete grade 5. In contrast there is a Latin American pattern in which enrolment in grade 1 is (nearly) universal but drop-out is the key problem. (Filmer, Pritchett, 1998, p. 3).

However, their conclusion does not contradict present results: 'These data cast some doubts on the notion that physical availability of school facilities at the primary or secondary level is the key issue in many countries' (Filmer, Pritchett, 1998, p. 4).

${ }^{38} \mathrm{He}$ notices that the lack of locally trained manpower attracts expatriates, who have higher reservation wages and are often remunerated with grant aid, thus crowding out local competencies even further. Also, Schultz (1988) found a negative effect of teacher wages on primary and secondary enrolment.

${ }^{39}$ Analogous measures obtain for the random-effects model (available from the author).

${ }^{40}$ Estimates not reported in Table 3, but available from the author.

${ }^{41}$ It also renders the Gini coefficient insignificant, but it remains significant in random-effects estimation using robust estimators. The Gini coefficient also remains significant when analysing yearly cross-section, whereas at regional level its significance seems more attributable to North African and South-Asian countries (all estimates available from the author).

${ }^{42}$ Given the reduction in the number of countries/years for which information is available, we could introduce sample selection biases. However, when we compare the full sample estimates (column 1 of Table 3 ) with the reduced sample (column 1 of Table 4, we notice that the size and significance of the coefficients are not modified.

${ }^{43}$ From column 3 of Table 4 , taking the total derivative of secondary enrolment with respect to government expenditure on education over GDP yields positive values for the Gini index above 0.37 .

${ }^{44}$ See Card (1999).

${ }^{45}$ The variable 'average years of primary education' (the sample mean for the population over 15 is 3.96 years) is obtained by multiplying the variable 'share of the population with completed and uncompleted primary education' (the sample mean for the population over 15 is 0.632 ) with the variable 'years of duration of primary education' (the sample mean for 1965 is 6.31). Therefore, an increase of 1 year in the average years of primary education can be obtained by increasing the primary attendance in the population by 0.158 (obtained as result of 1/6.31).

${ }^{46}$ These two channels cannot be tested directly because of the lack of appropriate data. Estimates of returns to schooling for several countries (but limited to very few years) are reported in Psacharopoulos (1994). Unemployment rates for 
educational attainment do not exist on such a long time span and for so many countries.

${ }^{47}$ A rather plausible assumption: see Benabou (1996b, c).

${ }^{48}$ This evidence is confirmed by including another variable, the 'ratio of total workers to population', which Barro and Lee (1994) report as drawn from Summer and Heston (1991), and extends up to 1985. We have been unable to update this variable in a consistent way. However, if we re-estimate the model reported in column 1 of Table 3 over the period 1960-85 including this variable, it turns out to be significant, with the coefficient equal to 0.491 (1.96). This implies that an increase in the employment rate of 10 per cent calls for an increase in secondary enrolment of almost 5 per cent. This seems unrelated to the type of secondary education that is available: a variable measuring the share of vocational education in secondary education is statistically insignificant.

${ }^{49} \mathrm{~A}$ negative coefficient for the Gini coefficient is obtained in the random-effects estimation and for some cross-sections (especially 1970 and 1980).

${ }^{50}$ Here again, the data (using the specification of column 1 in Table 5) do not reject the restriction coefficient $(\log Y)=-\operatorname{coefficient}(G): F(1,226)=0.03(p=0.86)$.

${ }^{51}$ One could imagine the possibility that education at later stages could influence enrolment at earlier stages (think of the case of limited access to university reducing the enrolment to secondary schools). While being valid in principle, this objection neglects the fact that it is always possible to create a private supply of the rationed good.

${ }^{52}$ We would also have expected a negative correlation between the share of students enrolled in vocational secondary schools and enrolment to university (since students from generalist secondary schools are inputs to higher education), but this does not arise in our data.

${ }^{53}$ In the case of primary education, for homogeneity with secondary and tertiary education, we have re-estimated the model reported in Table 2, replacing the variable 'Share of the corresponding population over 15 with some primary education' with 'Average years of education in the population over 15 with some primary education'. While the former was statistically insignificant, the latter is significant.

${ }_{54} \mathrm{An}$ alternative explanation of the same evidence is put forward by Bourguignon and Verdier (2000). They present a model where an oligarchic class decides upon the optimal size of the poor to be educated. Since the franchise is one to one with education, the latter variable feeds back into taxation and redistribution decided upon by majority voting. Thus, when inequality is high, majority voting is likely to produce strong redistribution, and therefore the oligarchy has an incentive to restrict the access to education. However, their explanation is valid provided democratic participation is positively correlated with educational achievements. Since the former variable is difficult to define, this constitutes the focus of future research.

${ }^{55}$ This incorporates the direct effect (first line of Table 6) and the indirect effect (first line times third line lagged for one level).

${ }^{56}$ This policy advice is typically based on the comparison between private and social returns to education. Since the usual ranking of returns is primary $>$ secondary $>$ tertiary, there should be grounds to claim an expenditure reallocation in favour of the primary level. See Birdsall and James (1993) and Psacharopoulos (1994).

${ }^{57}$ For this reason the following conclusion does not seem to be supported: ' . . preliminary evidence suggests that the second pattern - restricted public sector 
capacity and a large private sector - is superior with respect to access, providing much higher overall enrolment ratios and thus higher rates of participation by lower-income groups' (Birdsall, James, 1993, p. 344).

\section{References}

Alesina A. (1998) 'The Political Economy of Macroeconomic Stabilization and Income Inequality: Myths and Reality' in Tanzi V. and Chu K. (eds.) Income Distribution and High-quality Growth, Cambridge, MA: MIT Press.

Alesina A. and Perotti R. (1996) 'Income Distribution, Political Instability and Growth', European Economic Review 40(6): 1203-1228.

Alesina A. and Rodrik D. (1994) 'Redistributive Politics and Economic Growth', Quarterly Journal of Economics 109: 465-490.

Arnove R., Franz S., Morse K. and Torres C. (1997) 'Education and Development' in Hillman R. (ed.) Understanding Contemporary Latin America, Boulder: Lynne Rienner.

Atkinson A. B. and Brandolini A. (2001) 'Promise and Pitfalls in the Use of "secondary" Data-sets: Income Inequality in OECD Countries as a Case Study', Journal of Economic Literature 39(3): 771-799.

Banerjee A. and Newman A. (1993) 'Occupational Choice and the Process of Development', Journal of Political Economy 101(2): 274-298.

Barro R. (1991) 'Economic Growth in a Cross Section of Countries', Quarterly Journal of Economics 106(2): 407-444.

Barro R. (1997) Determinants of Economic Growth - A Cross-empirical Study, Cambridge, MA: MIT Press.

Barro R. (2000) 'Inequality and Growth in a Panel of Countries', Journal of Economic Growth 5: 5-32.

Barro R. and Lee J. W. (1993) 'International Comparisons of Educational Attainment', Journal of Monetary Economics 32(3): 363-394.

Barro R. and Lee J. W. (1994) Data Set for a Panel of 138 Countries, Washington, DC: World Bank.

Barro R. and Lee J. W. (1996) 'International Measures of Schooling Years and Schooling Quality', American Economic Review, Papers and Proceedings 86(2): 218-223.

Barro R. and Lee J. W. (1997) 'Schooling Quality in a Cross Section of Countries', NBER Working Paper 6198, September.

Barro R. and Lee J. W. (2001) 'International Data on Educational Attainment: Updates and Implications', Oxford Economic Papers 3: 541-563.

Becker G. (1993) Human Capital: A Theoretical and Empirical Analysis, with Special Reference to Education, Chicago: University of Chicago Press (first edn 1964).

Becker G. and Tomes N. (1986) 'Human Capital and the Rise and Fall of Families', Journal of Labor Economics 4: S1-S39.

Benabou R. (1996a) 'Equity and Efficiency in Human Capital Investment: The Local Connection', Review of Economic Studies 63: 237-264.

Benabou R. (1996b) 'Heterogeneity, Stratification and Growth: Macroeconomic Implications of the Community Structure and School Finance', American Economic Review 86(3): 584-609. 
Benabou R. (1996c) 'Inequality and Growth' in Bernanke B. and Rotemberg J. (eds.) NBER Macroeconomic Annual 1996, Cambridge, MA: MIT Press.

Bertola G. (1993) 'Factor Shares and Savings in Endogenous Growth', American Economic Review 83(5): 1184-1198.

Birdsall N. and James E. (1993) 'Efficiency and Equity in Social Spending: How and Why Governments Misbehave' in Lipton M. and Van Der Gaag J. (eds.) Including the Poor, Washington, DC: World Bank.

Bourguignon F. (1994) 'Growth, Distribution and Human Resources' in Ranis G. (ed.) En Route to Modern Growth, Baltimore: Johns Hopkins University Press.

Bourguignon F. and Verdier T. (2000) 'Oligarchy, Democracy, Inequality and Growth', Journal of Development Economics 62(2): 285-313.

Brandolini A. and Rossi N. (1998) 'Income Distribution and Growth in Industrial Countries' in Tanzi V. and Chu K. (eds.) Income Distribution and Highquality Growth, Cambridge, MA: MIT Press.

Card D. (1999) 'The Causal Effect of Education on Earnings' in Ashenfelter O. and Card D. (eds.) Handbook of Labor Economics, Vol. 5, Amsterdam: Elsevier.

Chiu W. (1998) 'Income Inequality, Human Capital Accumulation and Economic Performance', Economic Journal 108: 44-59.

Cowell F. (1995) Measuring Inequality, London: Prentice Hall.

Deininger K. and Squire L. (1996) 'A New Data Set Measuring Income Inequality', World Bank Economic Review 10(3): 565-591.

Filmer D. and Pritchett L. (1999) 'The Effect of Household Wealth on Educational Attainment: Evidence from 35 Countries', Population and Development Review 25(1): 85-120 (also World Bank Policy Research Working Paper 1998 No. 1980).

Flug K., Spilimbergo A. and Wachtenheim E. (1998) 'Investment in Education: Do Economic Volatility and Credit Constraints Matter?', Journal of Development Economics 55: 465-481.

Forbes K. (2000) 'A Reassessment of the Relationship between Inequality and Growth', American Economic Review 90(4): 865-887.

Fuente A. de la and Doménech R. (2001) 'Schooling Data, Technological Diffusion, and the Neoclassical Model', American Economic Review 91(2): 323-327.

Galor O. and Zeira J. (1993) 'Income Distribution and Macroeconomics', Review of Economic Studies 60: 35-52.

Grilli E. (1994) 'Long-term Economic Growth, Income Distribution and Poverty in Developing Countries: The Evidence' in Grilli E. and Salvatore D. (eds.) Handbook of Economic Development, London: Greenwood Publishing Group.

Hanushek E. (1986) 'The Economics of Schooling: Production and Efficiency in Public School', Journal of Economic Literature 24: 1141-1177.

Hanushek E. (1995) 'Interpreting Recent Research on Schooling in Developing Countries', The World Bank Research Observer 10(2): 227-246.

Hanushek E. (1996) 'Measuring Investment in Education', Journal of Economic Perspectives 10(4): 9-30.

Ichino A. and Winter-Ebmer R. (1999) 'Lower and Upper Bounds of Returns to Schooling. An Exercise in IV Estimation with Different Instruments', European Economic Review 43(4-6): 889-901. 
Jones C. (1997) 'On the Evolution of the World Income Distribution', Journal of Economic Perspectives 11(3): 19-36.

Kuznets S. (1955) 'Economic Growth and Income Inequality', American Economic Review 45: 1-28.

Li H., Squire L. and Zou H. (1998) 'Explaining International and Intertemporal Variations in Income Inequality', Economic Journal 108: 26-43.

Mauro P. (1995) 'Corruption, Country Risk and Growth', Quarterly Journal of Economics 3: 681-712.

Nehru V. and Dhareshwar A. (1993) 'A New Database on Physical Capital Stock: Sources, Methodology and Results', Rivista de Analisis Economico 8(1): $37-59$.

Perotti R. (1993) 'Political Equilibrium, Income Distribution and Growth', Review of Economic Studies 60: 755-776.

Perotti R. (1994) 'Income Distribution and Investment', European Economic Review 38: 827-835.

Perotti R. (1996) 'Growth, Income Distribution and Democracy: What the Data Say', Journal of Economic Growth 1(2): 149-187.

Persson T. and Tabellini G. (1994) 'Is Inequality Harmful for Growth?', American Economic Review 84(3): 600-621.

Piketty T. (1997) 'The Dynamics of the Wealth Distribution and the Interest Rate with Credit Rationing', Review of Economic Studies 64(2): 173-189.

Psacharopoulos G. (1994) 'Returns to Investment in Education: A Global Update', World Development 22(9): 1325-1343.

Ridker R. (1994) The World Bank's Role in Human Resources Development in Sub-Saharan Africa, Washington, DC: World Bank.

Schultz P. (1988) 'Education Investments and Returns' in Chenery H. and Srinivasan T. (eds.) Handbook of Development Economics, Vol. 1, London: North Holland.

Sen A. (1976) 'Real National Income', Review of Economic Studies 43: 19-39.

Summers R. and Heston A. (1991) 'The Penn World Table (Mark 5): An Expanded Set of International Comparisons, 1950-1988', Quarterly Journal of Economics 56(2): 327-368.

Tibaijuka A. and Cormack A. (1998) 'Financing the Social Sectors in Sub Saharan Africa: A Review of the Literature', Unpublished manuscript, WIDER.

Torvik R. (1993) 'Talent, Growth and Income Distribution', Scandinavian Journal of Economics 95(4): 581-596.

UNDP (1997) Human Development Report 1997, Oxford: Oxford University Press.

UNESCO (1998) Statistical Yearbook, New York: UNESCO.

Weiner M. (1991) The Child and the State in India, New Delhi: Oxford University Press.

World Bank (1998) World Bank Data on CD-ROM, Washington, DC: World Bank. 
LABR1 3/6/03 07:31 PM Page 50 


\section{$L A B R$}

Volume 17, 2003

BSA article no: 001

\section{AUTHOR QUERY FORM}

Dear Author

During the preparation of your manuscript, the questions listed below have arisen. Please answer all the queries (marking any other corrections on the proof enclosed) and return this form with your proofs.

\begin{tabular}{|l|l|l|}
\hline Query no. & Query & Reply \\
\hline 1 & $\begin{array}{l}\text { Au: Please advise in the copyright line, } \\
\text { 'Publishers' change to Publishing. }\end{array}$ & \\
\hline
\end{tabular}

